\title{
Sovereign Borrowing by Developing Countries: What Determines Market Access?
}

\author{
R. Gaston Gelos, Ratna Sahay, \\ and Guido Sandleris
}




\title{
IMF Working Paper
}

Western Hemisphere Department

\section{Sovereign Borrowing by Developing Countries: What Determines Market Access?}

\author{
Prepared by R. Gaston Gelos, Ratna Sahay, and Guido Sandleris ${ }^{1}$
}

November 2004

\begin{abstract}
This Working Paper should not be reported as representing the views of the IMF. The views expressed in this Working Paper are those of the author(s) and do not necessarily represent those of the IMF or IMF policy. Working Papers describe research in progress by the author(s) and are published to elicit comments and to further debate.

What determines the ability of governments from developing countries to access international credit markets? We examine this question using detailed data on sovereign bond issuances and public syndicated bank loans since 1982. We find that traditional measures of a country's links with the rest of the world (such as trade openness) and traditional liquidity and macroeconomic indicators do not help much in explaining market access. However, a country's vulnerability to shocks and the perceived quality of its policies and institutions appear to be important determinants of its government's ability to tap the markets. We are unable to detect strong punishment of defaulting countries by credit markets.
\end{abstract}

JEL Classification Numbers: F34, G15

Keywords: Sovereign debt, international capital markets, syndicated bank loans, bond markets, developing countries

Author(s) E-Mail Address: ggelos@imf.org, rsahay@imf.org,gms118@columbia.edu

\footnotetext{
${ }^{1}$ The authors wish to thank Abdul Abiad, Roberto Benelli, Andy Berg, Eduardo Borensztein, Fernando Broner, Daniel Cohen, Tito Cordella, Giovanni dell'Ariccia, David Grigorian, Olivier Jeanne, Gabriel Lopetegui, Catherine Pattillo, Alessandro Prati, Sergio Rebelo, Carmen Reinhart, Xavier Sala-i-Martin, Markus Rodlauer, Gabriel Sensenbrenner, Antonio Spilimbergo, Linda Tesar, Carlos Végh, Andy Wolfe, Jeromin Zettelmeyer, participants in the IMF Workshop on Macroeconomic Challenges in Developing Countries and the IMF's Western Hemisphere Department's seminar series for helpful comments and suggestions. Guido Sandleris was a Summer Intern at the IMF while he worked on this project. We are grateful to Neşe Erbil, Chi Nguyen, and Hulya Ulku for able research assistance.
} 
I. Introduction 3

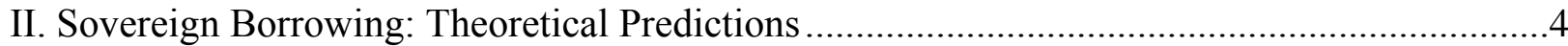

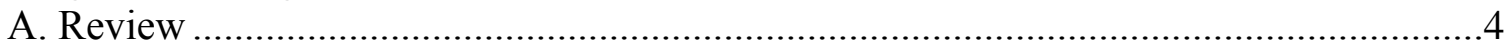

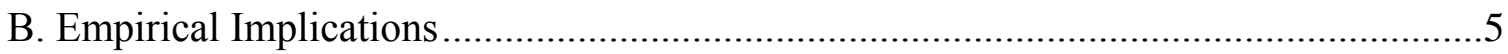

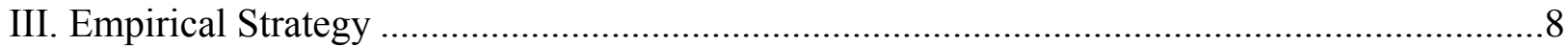

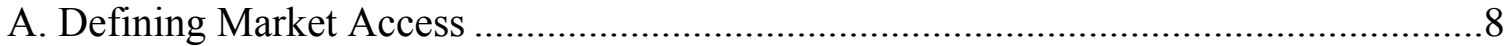

B. Overcoming Identification Problem ................................................................... 10

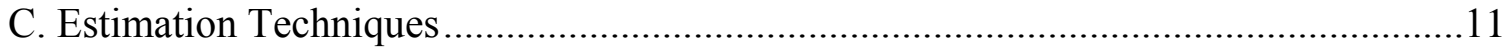

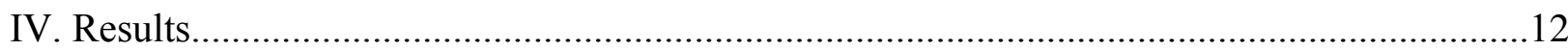

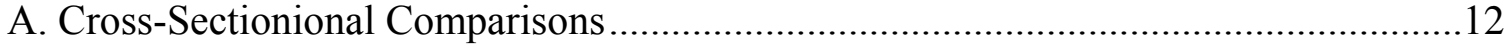

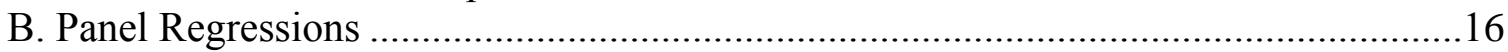

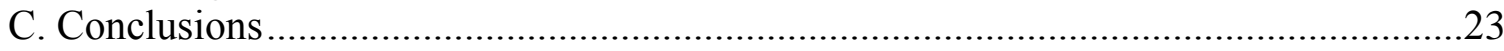

Figures

1. Total Net Private Lending to Public Sector in Developing Countries ...............................3

2. Access Frequency and Economic Size (GDP in U.S. dollars) ....................................15

3. Access Frequency and Income Volatility .............................................................15

4. Access Frequency and Foreign Direct Investment as a Fraction of GDP ......................15

Tables

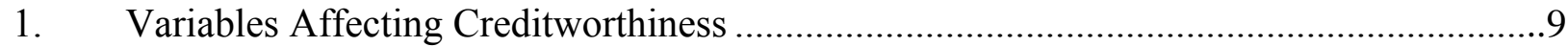

2. Means and Medians of Country Characteristics, by Access Frequency Groups ..............14

3. Determinants of Access Frequency (Tobit) ..............................................................17

4. Determinants of Access: Random-Effect Logit Model with Time Effects .....................20

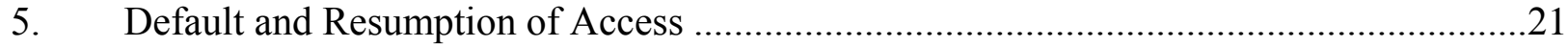

6. Relation between Official Flows and Probability of Observing No Access ...................21

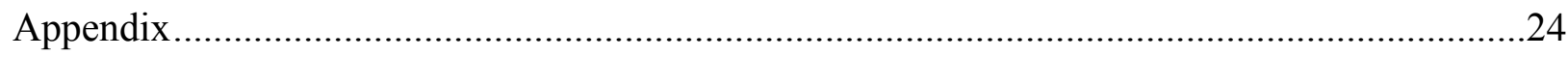

Apendix Tables

A1. Date of Inclusion of Formerly Centrally Planned Economies ....................................26

A2. Market Access, By Country ...............................................................................27

A3. Tests of Equality of Means and Medians Across Groups .............................................30

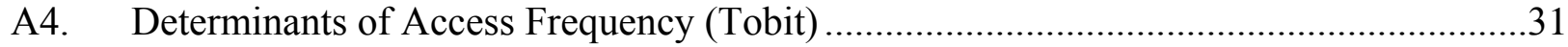

A5. Determinants of Access: Random-Effects Logit Model with Time Dummies.................33

A6. Determinants of Access: Fixed-Effect Logit Model with Time Dummies......................35

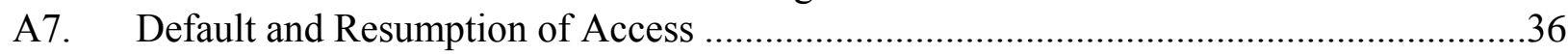

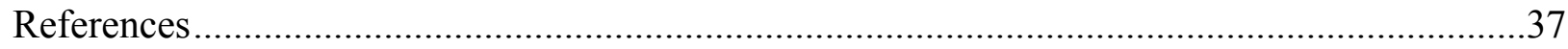




\section{INTRODUCTION}

A large and still-growing literature on capital flows to emerging markets has developed over the last decade addressing several aspects of these flows, including their determinants, composition, and volatility. ${ }^{2}$ What has been less studied, however, is why some countries are unable to issue sovereign debt in international markets or obtain loans from foreign private banks at all, even during periods of global lending expansions.

In this paper, we examine the ability of developing country governments to borrow from international credit markets over the different stages of the international credit market cycle. At what development stage can low-income countries expect to be able to tap the international capital markets? Which characteristics differentiate those countries that are able to borrow regularly from those that are only occasionally or never able to do so? To which extent do government policies matter for capital market access? A systematic empirical analysis of these issues seems to be missing.

We address these questions using data on individual bond issuances by sovereigns and syndicated bank loans that are extended directly to the government or guaranteed by it for the period extending from the outset of the Latin American debt crisis in 1982 until 2000. This is a period that includes both a subperiod of market stagnation and one of expansion when borrowing was easier (Figure 1). The inclusion of syndicated bank loans is important in enabling the analysis to capture the dominant form of sovereign lending during the 1980s.

Figure 1. Total Net Private Lending to Public Sector in Developing Countries

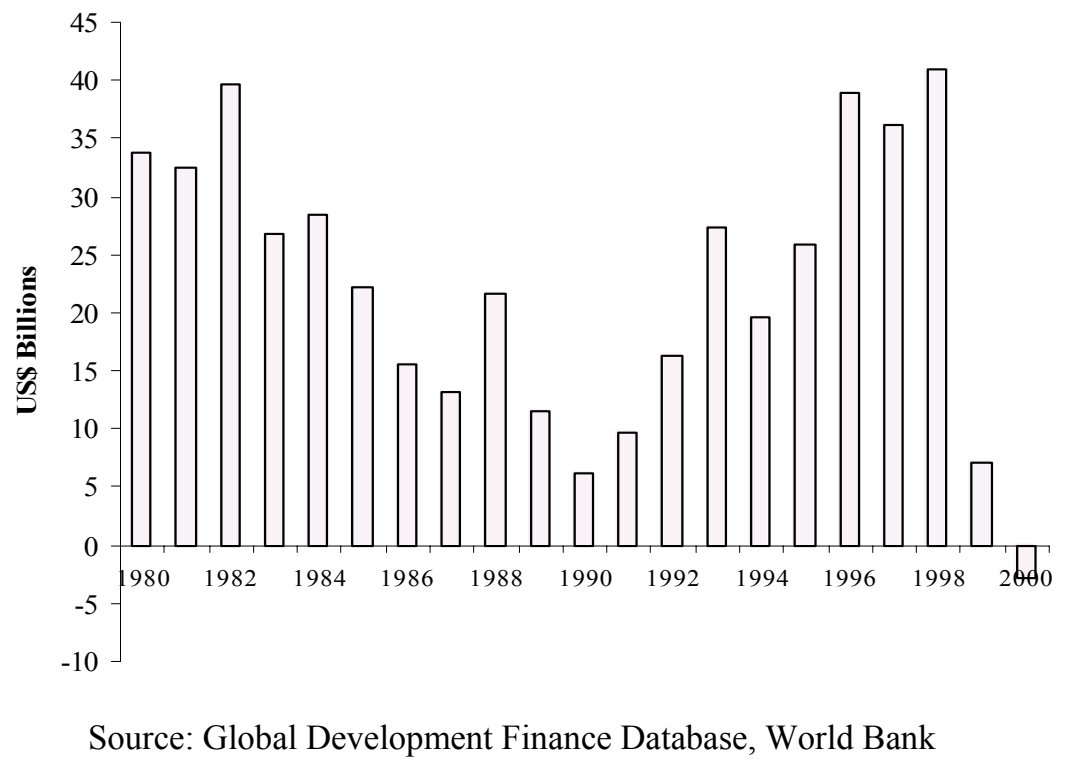

\footnotetext{
${ }^{2}$ See, for example, Calvo and Reinhart (1993), Fernandez-Arias (1996), Montiel and Reinhart (1999), and Mody and Taylor (2002).
} 
The existing empirical literature on sovereign borrowing has largely focused on explaining volumes and sovereign spreads, often overlooking the problem that many countries might be cut off from credit markets completely, at least temporarily. In the present study, we focus instead on the binary aspect: exclusion from or access to credit markets.

According to standard neoclassical economic theory, capital-scarce countries should be borrowing large amounts to finance domestic investment. ${ }^{3}$ We therefore study only developing countries that fall squarely into this category. Nevertheless, identification of supply versus demand shifts remains an issue inherent in any study of capital flows; here, we will take a series of careful steps to distinguish between actual rationing and voluntary abstention from borrowing.

We improve on the existing literature in several other aspects. (1) By using micro data, we are able to focus specifically on sovereign borrowing. (2) In addition to the factors typically stressed in the literature on sovereign borrowing, we investigate the importance of vulnerability — such as that emanating from a high exposure to terms of trade shocks - in determining credit constraints. This is an aspect which is particularly relevant for low-income countries; for political or humanitarian reasons, a country may not be in a position to service debt if its income falls below a certain, possibly subsistence, threshold level. ${ }^{4}$ (3) We explicitly examine the questions of the effect of defaults. (4) In order to measure policies, we go beyond the standard variables by using a previously unavailable index, developed by the World Bank, of the quality of policies and institutions. (5) The list and detail of explanatory variables significantly exceed those that have been employed to date in related studies.

We find that economies that do not access the markets usually suffer from greater political instability and worse perceptions of their policies and institutions, and are more vulnerable to external shocks. Surprisingly, the links of the economy to the world (such as the degree of trade openness or the share of Foreign Direct Investment, FDI) in GDP) stressed in parts of the literature do not seem to increase the probability of market access. Similarly, we do not find evidence for the hypothesis that resource-abundant countries can tap credit markets more easily. Finally, we were unable to detect a strong punishment of defaulting countries by credit markets.

\section{Sovereign Borrowing: Theoretical Predictions}

\section{A. Review}

Theory predicts that sovereign governments should borrow to smooth national consumption or to undertake investment projects that they could not finance otherwise. The ability of a sovereign government to borrow on international credit markets depends on its perceived ability to repay and on the incentives it will have to do it.

\footnotetext{
${ }^{3}$ See, for example, Lucas (1990).

${ }^{4}$ Recently, Catão and Sutton (2002) have examined the impact of income volatility on sovereign default probability.
} 
In recent years, the theoretical literature on sovereign borrowing has dealt mainly with the second of these issues: the country's willingness to repay. ${ }^{5}$ The question at the heart of the sovereign borrowing literature was why governments have an incentive to repay their debts with foreign creditors within the existing international legal framework. There is no bankruptcy code for sovereign borrowers and lenders cannot take control of a country nor seize a significant amount of its assets in the event of a sovereign default.

Economists have offered two main explanations for why governments may want to repay: reputation (exclusion from future credit) and direct sanctions. ${ }^{6}$ The reputation literature, starting with Eaton and Gersowitz (1981), develops the idea that repayment may hold the carrot of a good reputation for the borrower (implying either the ability to borrow again or, alternatively, better future borrowing conditions). However, their argument relies on the crucial assumption that a defaulting government is not only excluded from future credit markets but also from savings opportunities. In a seminal article, Bulow and Rogoff (1989a) show that if this assumption is dropped, the sole threat of exclusion from credit markets will not provide enough incentives to repay. They stress that instead of reputational concerns, it is the threat of direct sanctions (usually trade related) that makes governments repay. ${ }^{7}$ Cole and Kehoe (1997), however, argue that sanctions are not necessary because a default may negatively affect the government's reputation in some of its other "trust relationships" (such as those involving defense or labor issues) with the creditor. These reputation spillovers generate a cost of defaulting that could explain why governments repay.

While the abovementioned class of models has concentrated mostly on sovereign governments' willingness to repay, lenders will naturally also be concerned about ability to repay. Here, both issues of long-term solvency and short-term liquidity have been studied in different strands of the literature. ${ }^{8}$ The literature on these topics is too large to be surveyed here. See, for example, Detragiache and Spilimbergo (2001) for a model and a discussion of the liquidity crises literature and Cohen (1991) for an analysis of country solvency.

\section{B. Empirical Implications}

Turning to empirical implications, the repudiation models that allow for the existence of lending mostly predict credit rationing in the form of a debt ceiling. This upper bound of the

\footnotetext{
${ }^{5}$ In practice, there is no clear-cut distinction between a sovereign government's ability and willingness to repay. For example, while a government may in principle repay because a country's net worth is greater than its debt, repayment may not be feasible because it may either imply strong political opposition or severe humanitarian consequences (such as starvation). ${ }^{6}$ Comprehensive reviews of the literature can be found in Eaton and Fernandez (1995) and Obstfeld and Rogoff (1996).

${ }^{7}$ Several papers follow this intuition and make explicit use of direct sanctions to support sovereign borrowing including Bulow and Rogoff (1989b), Cohen (1991), Lane (1999), Gibson and Sundaresan (2002), and Rose (2002). Similarly, in Cohen and Sachs (1986) a fraction of a country's output is put up as collateral (and therefore lost upon default).

${ }^{8}$ Haque, Mark, and Mathieson (2000) distinguish between the "debt-service capacity approach" and the "cost-benefit approach" to examine country creditworthiness.
} 
debt a country is able to incur depends on the costs it has to pay in the event of a default. These costs are usually related to the links that a country has with the world (including reputation spillovers): trade and financial linkages such as FDI are specific examples. The bigger is a country's output, the larger is the punishment that can be imposed through trade sanctions and collateral seizure. ${ }^{9}$ Political instability should also negatively affect the amount a country can borrow. The shorter a government can expect to be in office, the higher are its incentives to take advantage of the immediate benefits of higher loans and to discount any future sanctions heavily. ${ }^{10}$ Lastly, global factors, in particular the world interest rate, will affect the cost of servicing the debt stock and the temptation to default. The repudiation literature, as in Eaton and Gersowitz (1981), suggests that income variability should have a positive effect on creditworthiness: countries that are more prone to shock have a higher interest in maintaining access to credit markets and are therefore less likely to default.

Therefore, we can write $L_{i}^{\max }$, the debt ceiling for country $i$ at time $t$, as a function of size, income volatility, political stability, the economy's productivity, links to the rest of the world, and global conditions factors ${ }^{11}$ :

$$
\left.L^{\max }=\underset{+}{f(S i z e, \text { Volatility }}, \underset{+}{\text { Productivity, Pol. Stability, Links }}+\underset{+}{+}+\text { World, Global Conditions }\right)
$$

However, in the context of poor countries, one might expect income variability to have a negative effect on creditworthiness. Borrowers may not be in a position to service debt if a country's income falls below a certain, possibly subsistence, threshold level. For this reason, lenders should not only be concerned about the absolute size of a country's GDP, but also about vulnerability, such as reflected in per-capita income and the variability of income. Countries with small per-capita income are more likely to experience a fall below a critical subsistence threshold. Similarly, countries with higher output volatility are more likely to suffer a drop in income below the minimum level below which a government may face insurmountable obstacles in servicing its debt. To our knowledge, this notion has not been explicitly considered in the context of sovereign borrowing.

The literature addressing solvency and liquidity issues suggests that lenders should be interested in a country's quality of policies and liquidity indicators such as the level of international reserves or the share of short-term debt in total debt.

Multilateral assistance can overcome liquidity problems and act as a "seal of approval" of sound economic policies. For this reason, we expect that IMF programs should have a positive impact on the ability of sovereigns to access credit markets. This has to be qualified, however, by the fact that many IMF programs, in particular those with a concessional element, impose strict limits on international private borrowing. It is therefore important to differentiate between different types of programs in the analysis.

\footnotetext{
${ }^{9}$ See Lane (2004).

${ }^{10}$ See Lane (2004) and Özler and Tabellini (1991).

${ }^{11}$ See Lane (2004) for a similar equation.
} 
Lastly, there might be fixed costs for borrowing through syndicated loans or bond issuances. This would be another reason why we might observe smaller countries accessing the markets less frequently.

\section{Variables used}

Following this discussion, Table 1 lists the set of variables affecting the probability of market access that we are going to employ. ${ }^{12}$ When signing the effect of the respective variable on the probability of market access, the table differentiates between the predictions of the repudiation literature of sovereign borrowing ("willingness to repay") and the predictions of the literature stressing the debt-service capacity ("ability to repay"). ${ }^{13}$

We measure size by GDP. We follow common practice in using the ratios of exports to debt service and of external reserves to months of imports as indicators of liquidity. ${ }^{14}$ To quantify a country's vulnerability and income volatility, we employ GDP per capita, the share of agriculture in GDP, the standard deviation of GDP growth over ten years, and the standard deviation of terms of trade measured over twenty years. GDP growth is used as a proxy for productivity and solvency. Countries with positive changes in the terms of trade and countries with resource abundance (as measured by the share of mining in GDP or the share of fuel exports) should be seen as more solvent.

To measure the quality of policies, we use the inflation rate, the real exchange rate deviation from its five-year moving average, the fiscal deficit, and a comprehensive, yearly index of the quality of policies and institutions developed by the World Bank. Large conflicts, coups, and wars have detrimental effects on country solvency, and we measure them with a widely used dataset on "State Failures". ${ }^{15}$ We capture links to the world through the share of FDI in GDP and trade openness (the sum of exports and imports divided by GDP). We measure political risk with the International Country Risk Guide's (ICRG) Political Risk Index. On defaults, we use data on defaults on foreign-currency debt based on Standard \& Poor's classification, as reported in Beers and Bhatia (1999). We differentiate between three types of IMF programs: Stand-By Arrangements, (EFFs), and Poverty Reduction and Growth Facility (PRGF)-supported programs. As explained in the Appendix, these programs are likely to differ in their impact on market access. While Stand-By Arrangements should in principle play a catalytic role for private financing, programs supported by the PRGF impose strict limits on sovereign borrowing from the private sector, and therefore, if anything, are likely to have a negative effect on market

\footnotetext{
${ }^{12}$ A more detailed description of the variables is given in the Appendix.

${ }^{13}$ See Haque and others.

${ }^{14}$ We considered including the share of short-term debt in total debt as an additional, commonly used measure of liquidity. However, a priori, the effect of a higher share of short-term debt on the probability of access at any given moment is ambiguous: while higher short-term debt increases the likelihood of a liquidity crisis, it also makes it more likely that a country will have to borrow at any given moment in time.

${ }^{15}$ We experimented with various other data sets on conflicts, wars, and coups, without changing the results reported in this paper.
} 
access. Lastly, we also assess the impact of market perceptions as reflected in the sovereign ratings by Institutional Investor. These ratings in turn are at least partly a function of the variables discussed above; this will be addressed in the econometric specifications.

\section{EMPIRICAL STRATEGY}

The theoretical literature briefly reviewed above largely makes predictions about the debt stock ceiling for countries; we are instead interested in explaining market access, i.e. flows at any given moment. ${ }^{16}$

We assume that countries always aim to move toward the debt ceiling, although adjustment may not be instantaneous. If the debt ceiling for country $i$ is binding at time $t$ $\left(L_{i, t}=L_{i, t}{ }^{\max }\right.$ ) we will observe no market access except for refinancing. If the ceiling increases $L_{i, t}{ }^{\max }>L_{i, t-1}{ }^{\max }$ (because of positive country or world developments), we will observe the country tapping the market. If the debt ceiling drops during an observation period, we will not observe access of any form during that time.

The identification problem that we have to overcome is that we might observe no access in cases in which the debt ceiling is not binding $\left(L_{i, t}<L_{i, t}{ }^{\max }\right)$, but in which a country does not want to borrow. We will discuss this issue below. First, we define our empirical measure of market access.

\section{A. Defining Market Access}

We define access as public or publicly guaranteed bond issuances or public or publicly guaranteed borrowing through a private syndicated bank loan that results in an increase in the country's indebtedness. ${ }^{17}$ The literature has often focused exclusively on bonds. However, particularly in the 1970's and 1980's, syndicated bank loans were the prominent form of sovereign borrowing by developing countries, so that it would be misleading to omit them in a study that includes that period. Note that syndicated loans are relatively more complex instruments than standard loans or trade credit. ${ }^{18}$ Therefore, when a country uses these instruments we can interpret this borrowing as a qualitative jump in their ability to tap the markets.

\footnotetext{
${ }^{16}$ Lane (2004) focuses on total debt stocks.

${ }^{17}$ To exclude case where $L_{i, t}{ }^{\max }$ falls but the country still is able to roll over part of its debt, we only classify as access those cases of issuance in which the total stock of commercial public debt (as given by data from the Global Development Finance database) does not fall.

${ }^{18}$ Gale (2001) examines the determinants of the choice between international debt instruments by emerging market borrowers.
} 
Table 1. Variables Affecting Creditworthiness

\begin{tabular}{|c|c|c|c|}
\hline \multirow[t]{2}{*}{ Category } & \multirow[t]{2}{*}{ Variable } & \multicolumn{2}{|c|}{ Expected Sign } \\
\hline & & $\begin{array}{l}\text { Repudiation } \\
\text { literature }\end{array}$ & $\begin{array}{l}\text { Debt service } \\
\text { capacity }\end{array}$ \\
\hline Size & GDP (billion US\$) & + & + \\
\hline \multirow[t]{2}{*}{ Liquidity } & Exports/Debt service & + & + \\
\hline & Reserves/months of imports & n.a. & + \\
\hline \multirow{4}{*}{$\begin{array}{l}\text { Volatility/ } \\
\text { vulnerability }\end{array}$} & GDP per capita (US\$) & - & + \\
\hline & Agriculture/GDP (percent) & + & - \\
\hline & Std. dev. GDP growth (10yrs) & + & - \\
\hline & Std. dev./ terms of trade (20 yrs) & + & - \\
\hline \multirow{11}{*}{$\begin{array}{l}\text { Productivity/ } \\
\text { solvency/quality of } \\
\text { policies }\end{array}$} & GDP growth (percent) & + & + \\
\hline & Mining/GDP & + & + \\
\hline & Fuel exports/total exports & + & + \\
\hline & Export growth & + & + \\
\hline & Inflation & - & - \\
\hline & Change in terms of trade & & + \\
\hline & $\begin{array}{l}\text { Real exchange rate deviation } \\
\text { from 5-year average (in percent) }\end{array}$ & - & - \\
\hline & Fiscal deficit/GDP (percent) & n.a. & + \\
\hline & Arrears/total debt & n.a. & - \\
\hline & $\begin{array}{l}\text { World Bank Index of Quality of } \\
\text { Policies (CPIA) }\end{array}$ & + & + \\
\hline & "State failures" & n.a. & - \\
\hline \multirow[t]{2}{*}{ Links to world } & FDI/GDP & + & n.a. \\
\hline & Openness (Exp+ Imp/GDP) & + & + \\
\hline Political risk & ICRG Index of Political Risk & + & + \\
\hline \multirow[t]{2}{*}{ IMF programs } & SBA, EFF & + & + \\
\hline & PRGF & - & - \\
\hline Market perceptions & Institutional Investor Index & + & + \\
\hline
\end{tabular}


The data on public sector borrowing from international markets are provided by Capital Data (Bondware and Loanware) and contain information on 2053 individual bond issuances and 5065 commercial bank syndicated loans to 144 developing countries ${ }^{19}$. To check the robustness of our results with respect to our definition of "access", we use aggregate data from the World bank's Global Development Finance database in addition. There, we define market access in period " $t$ " as the existence of positive net total flows in the form of bonds and commercial bank loans to the public sector.

The existing empirical literature on sovereign borrowing has largely concentrated on explaining sovereign spreads or volumes of capital flows, ignoring the factors that allow countries to obtain credit in the first place. Expressed differently, the literature has often overlooked the censoring problem induced by credit rationing, examining only the terms for those countries for which we observe access. ${ }^{20} \mathrm{We}$ approach the question from the opposite angle, focusing only on zeroes and ones.

\section{B. Overcoming Identification Problem}

In order to distinguish between actual rationing and voluntary abstention from borrowing, we take the following steps.

(1) We exclude industrial countries from our sample. A prima facie case for continuous willingness to borrow exists only in the case of developing countries. Given their need to catch up with the advanced countries, any neoclassical model would predict that these economies should in principle be borrowing vast sums from the rich world. ${ }^{21}$

(2) We also exclude countries classified by the IMF's World Economic Outlook as "creditor countries". These are the oil producing countries Kuwait, Libya, Oman, Qatar, Saudi Arabia, and the United Arab Emirates.

(3) Since many communist/socialist countries were ideologically opposed to borrowing internationally from private markets, we include them only after they started to initiate market

\footnotetext{
${ }^{19}$ For further details on the data, see the Appendix.

${ }^{20}$ Cantor and Packer (1996) study the determinants of spreads for sovereign bonds and bonds and syndicated loans respectively during the 1990s. Dooley, Fernández-Arias, and Kletzer
} (1996) explore the factors driving secondary debt market prices of middle-income countries. Özler (1993) examines the impact of sovereign borrowers' previous repayment history on bank loans spreads for 26 developing countries between 1968-1981. Edwards (1986) studies bond spreads in 1976-80 and Eichengreen and Portes (1989) examine bonds issued in the 1920s. In a different approach, Lane (2004) studies the determinants of total debt stocks across countries. Some papers, such as Eichengreen and Mody (1998) and Dell'Ariccia, Schnabel, and Zettelmeyer (2002) model the decision of the borrower to issue debt separately in a selection equation. However, the possibility that one does not observe issuance because of strict credit rationing is not taken into account. There is an analogy to the censoring problem in the literature on credit rationing for firms: see Gelos and Werner (2002).

${ }^{21}$ See, for example, Lucas (1990). 
reforms and became more outward looking, unless we observe them borrowing earlier. A complete list of countries and starting dates of inclusion is given in the Appendix (Table A1).

(4) We exclude cases in which we do not observe market access by sovereigns but in which we observe the private sector of that country borrowing internationally. It is very unlikely that the private sector has access to international credit markets while the sovereign remains credit constrained.

(5) We aggregate the borrowing information by year. It is very plausible that a developing country would not want to borrow in a particular month or quarter either because it just has borrowed substantially or because it hopes to obtain better borrowing terms in the near future. However, it is more difficult to explain why a country would not want to borrow at all, neither through bank loans or bond issuances during the course of a whole year.

(6) We examine the possibility that countries substitute between private and official flows (poor countries may want to abstain from private capital markets if they can receive enough official funds at cheaper rates), finding no evidence for such a substitution. We find that, if anything, private and official capital flows seem to complement each other.

(7) In a first characterization of the data, we group countries according to their frequency of borrowing into three main groups. By forming these three groups on the basis of their borrowing record over a long time period, this comparison largely overcomes the problems associated with identifying nonborrowers as credit constrained.

(8) In our panel estimations, we control for time-varying aggregate factors such as world interest rates.

An alternative strategy would have been to try to estimate demand and supply curves separately, as done, among others, in Hajvassiliou (1987), Mody and Taylor (2002), or Kahras and Shihido (1991). We did not pursue this avenue. There are many methodological problems associated with such techniques, and no convincing solution has yet been proposed. For example, some models of credit rationing, such as the one in Stiglitz and Weiss (1981) do imply backward-looking supply curves, an issue which is typically ignored in the linear specifications used in the literature. In this light, for the present purpose we feel more confident with the strategy described here than with an econometric technique that involves considerable model and specification uncertainties.

Figure 2 shows the dates of market access according to our definition, excluding the cases described in (1)-(4) of this subsection.

\section{Estimation Techniques}

We first focus on cross-sectional differences. We divide our sample into three different groups according to their success in accessing the international credit during 1984-98:

(i) countries that never had access during the period, (ii) countries that gain or regain access in the period but do not access the market all the time, and (iii) countries that nearly always had access during the period, borrowing frequently. We then examine whether there are significant 
differences in identifiable country characteristics across these three groups. In an extension, we attempt to explain the number of times that countries tapped the markets over the entire sample period by observable country characteristics.

Finally, we complement this analysis by a panel approach, where we control for timevarying factors and unobservable country characteristics and ask whether variations in country characteristics over time, in particular policies, help explain access.

\section{RESULTS}

\section{A. Cross-Sectional Comparisons}

We first divide our sample of 144 developing countries in three different groups according to their success in accessing the international credit markets in the last two decades:

- No access: Strikingly, the group of countries that according to our definition never accessed international credit markets (no access) in the sample period is very large, with 60 countries, or more than 40 percent of the total sample.

- Occasional access: Countries that gain or regain access in the period but do not manage to access the market all the time. Specifically, we included countries with less than 14 years of access (out of 20). Most countries (74) fall into this intermediate group.

- Consistent access: Countries that accessed during most years (at least 14 years). Only 10 countries fall into this category.

Next, we compare the characteristics of the countries in the three groups to assess whether there are any discernible country characteristics that help to explain their differential ability to access the markets (Table 2). To test formally whether the explanatory variables are different across groups of countries, we carry out tests for the equality of means and medians (Appendix, Table A3). ${ }^{22}$

The formal comparisons show the following:

- Size. Group 0 (no access) and group 3 (consistent access) clearly differ in the size of their economies. The variable is not significantly different between groups 1 (occasional access) and 3 (Figure 2).

- Debt/Liquidity. The stock of debt at the outset of the debt crisis is significantly lower for the consistent access group than for the others. Countries that consistently access markets also tend to have higher exports-to-debt service ratios.

- Vulnerability. The results on differences in GDP per capita are not clear cut. The "no access" group has significantly higher GDP agriculture shares than the other two groups. The

${ }^{22}$ As a comparison of means only may be misleading in the presence of large outliers. 
volatility of output and of the terms-of-trade tends to be smaller for countries that access consistently than for those who do not (Figure 3). ${ }^{23}$

- Productivity/Solvency/Quality of policies. Fiscal deficits are not consistently different across the three main groups. However, GDP growth is significantly higher for the consistent access group than for the others. Moreover, the CPIA index of macroeconomic policies and institutional quality is positively related to capital access. Inflation also seems to be lower in countries with more frequent market access. The results on resource abundance are inconclusive. The incidence of "state failures" is not significantly different across groups. On arrears, there is a significant difference between the "consistent access" (which had no arrears), and the other groups.

- Links. FDI investment does not appear to capture any links to the rest of the world that are relevant for market access (Figure 4). The evidence on trade openness contradicts theoretical predictions: the countries with consistent market access are less open than those with no market access (although the difference is not consistently statistically significant).

- Political risk. While this variable is available for only a subset of countries, the comparison provides some indication that higher political risk is associated with less access.

- IMF programs. Countries with no capital access are less likely to have an SBA-supported IMF program than countries with occasional access. Countries with no capital access do not have EFF programs; countries with no or little market access are more likely to have a PRGF. The latter is not surprising given that PRGF-type programs are not only limited to low-income countries with debt sustainability problems but also impose strict limits on external borrowing from the private sector.

- Market perceptions. Institutional Investor Ratings differ significantly across groups (Figure 3), with higher ratings being associated with higher access frequency.

Most of these results are confirmed by simple Tobit regressions explaining access frequency across countries (Appendix, Table A4). The statistically significant variables were GDP, the share of agriculture in GDP, GDP per capita, terms-of-trade volatility, IMF programs (PRGF's with a negative sign), the ICRG Political Risk index, the CPIA policy quality index, the Institutional Investor rating, and the Transition and Africa dummies. The existence of arrears has a negative effect on the probability of market access.

${ }^{23}$ The share of agriculture in GDP was found to be a statistically significant determinant of debt reschedulings in Berg and Sachs (1988). 
Table 2. Means and Medians of Country Characteristics, by Access Frequency Groups

\begin{tabular}{|c|c|c|c|c|c|c|c|c|c|c|}
\hline & & \multicolumn{3}{|c|}{ No Access } & \multicolumn{3}{|c|}{ Occasional Access } & \multicolumn{3}{|c|}{ Consistent Access } \\
\hline & Variable & $N$ & Mean & Median & $N$ & Mean & Median & $N$ & Mean & Median \\
\hline Size & GDP (bill. US\$) & 59 & 7.5 & 2.1 & 72 & 38.0 & 9.7 & 9 & 136.0 & 89.3 \\
\hline \multirow[t]{3}{*}{ Debt/liquidity } & $\begin{array}{l}\text { Total Debt } \\
\text { 1981/GDP } \\
\text { (percent) }\end{array}$ & 39 & 49 & 34 & 46 & 44 & 39 & 6 & 22 & 26 \\
\hline & $\begin{array}{l}\text { Exports/Debt } \\
\text { Service }\end{array}$ & 52 & 65.8 & 17.6 & 67 & 101.8 & 7.6 & 8 & 7.5 & 7.9 \\
\hline & $\begin{array}{l}\text { Reserves/months } \\
\text { of Imports }\end{array}$ & 54 & 3.0 & 2.3 & 70 & 3.2 & 2.8 & 10 & 4.2 & 4.1 \\
\hline \multirow[t]{4}{*}{$\begin{array}{l}\text { Volatility/ } \\
\text { vulnerability }\end{array}$} & $\begin{array}{l}\text { GDP per capita } \\
(\mathrm{US} \$)\end{array}$ & 59 & 1686 & 685 & 72 & 1954 & 1467 & 9 & 3214 & 2209 \\
\hline & $\begin{array}{l}\text { Agriculture/GDP } \\
\text { (percent) }\end{array}$ & 58 & 28 & 28 & 69 & 20 & 18 & 10 & 14.5 & 15.5 \\
\hline & $\begin{array}{l}\text { Std. dev. GDP } \\
\text { growth }(10 \mathrm{yrs})\end{array}$ & 60 & 6.1 & 4.8 & 71 & 5.6 & 4.8 & 10 & 3.5 & 3.5 \\
\hline & $\begin{array}{l}\text { Std. dev. } \\
\text { Terms of Trade }(20 \\
\text { yrs })\end{array}$ & 34 & 103.2 & 117.4 & 46 & 87.5 & 93.4 & 7 & 71.1 & 89.4 \\
\hline \multirow[t]{9}{*}{$\begin{array}{l}\text { Productivity/ } \\
\text { Solvency }\end{array}$} & $\begin{array}{l}\text { GDP growth } \\
\text { (percent) }\end{array}$ & 59 & 3.0 & 2.9 & 72 & 1.9 & 2.1 & 9 & 5.1 & 5.2 \\
\hline & $\begin{array}{l}\text { Mining/GDP } \\
\text { (percent) }\end{array}$ & 36 & 6 & 1 & 54 & 6 & 3 & 10 & 5 & 3 \\
\hline & $\begin{array}{l}\text { Fuel exports/Total } \\
\text { exports }\end{array}$ & 44 & 5.5 & 0.2 & 65 & 6.8 & 1.5 & 9 & 11.1 & 1.8 \\
\hline & $\begin{array}{l}\text { Export growth } \\
\text { (percent) }\end{array}$ & 60 & 8.0 & 6.0 & 70 & 5.0 & 5.0 & 10 & 10.0 & 10.0 \\
\hline & Inflation (percent) & 59 & 98.5 & 9.8 & 72 & 119.4 & 21.2 & 10 & 13.3 & 6.6 \\
\hline & $\begin{array}{l}\text { Fiscal deficit/GDP } \\
\text { (percent) }\end{array}$ & 28 & 5 & 4 & 45 & 4 & 3 & 8 & 4 & 4 \\
\hline & Arrears/Tot. Debt & 52 & 0.04 & 0.01 & 68 & 0.03 & 0.01 & 12 & 0.00 & 0.00 \\
\hline & CPIA & 57 & 2.69 & 2.85 & 68 & 3.05 & 3.05 & 9 & 3.92 & 3.77 \\
\hline & "State Failures" & 52 & 0.18 & 0.00 & 74 & 0.21 & 0.00 & 10 & 0.29 & 0.10 \\
\hline \multirow{2}{*}{$\begin{array}{l}\text { Links to } \\
\text { world }\end{array}$} & FDI/GDP & 60 & 0.03 & 0.01 & 69 & 0.02 & 0.01 & 9 & 0.02 & 0.02 \\
\hline & $\begin{array}{l}\text { Openness }\left(\mathrm{Exp}^{+}\right. \\
\text {Imp/GDP) }\end{array}$ & 59 & 0.82 & 0.78 & 71 & 0.71 & 0.64 & 9 & 0.75 & 0.48 \\
\hline Political risk & $\begin{array}{l}\text { ICRG Index of } \\
\text { Political Risk }\end{array}$ & 32 & 53.3 & 52.7 & 63 & 57.6 & 58.3 & 10 & 62.1 & 63.5 \\
\hline $\begin{array}{l}\text { Market } \\
\text { perceptions }\end{array}$ & $\begin{array}{l}\text { Institutional } \\
\text { Investor Rating }\end{array}$ & 29 & 16.0 & 15.2 & 62 & 29.6 & 28.1 & 9 & 50.1 & 45.9 \\
\hline \multirow[t]{3}{*}{ IMF } & $\begin{array}{l}\text { SBA (percent of } \\
\text { yrs) }\end{array}$ & 60 & 0.07 & 0.06 & 74 & 0.14 & 0.14 & 10 & 0.05 & 0.08 \\
\hline & $\begin{array}{l}\text { EFF (percent of } \\
\text { yrs) }\end{array}$ & 60 & 0.01 & 0.00 & 74 & 0.03 & 0.04 & 10 & 0.01 & 0.00 \\
\hline & $\begin{array}{l}\text { PRGF (percent of } \\
\text { yrs) }\end{array}$ & 60 & 0.04 & 0.00 & 74 & 0.03 & 0.04 & 10 & 0.00 & 0.00 \\
\hline
\end{tabular}

Source: Authors' calculations based on data from Institutional Investor, International Country Risk Guide (ICRG), GDF, World Bank, and IMF. SBA denotes IMF Stand-By Arrangements, EFF stands for Extended Fund Facility, and PRGF stands for Poverty Reduction and Growth Facility. FDI denotes Foreign Direct Investment. CPIA stands for the World Bank's Country Policy and Institutional Assessment index. 
Figure 2. Access Frequency and Economic Size (GDP in U.S. dollars)

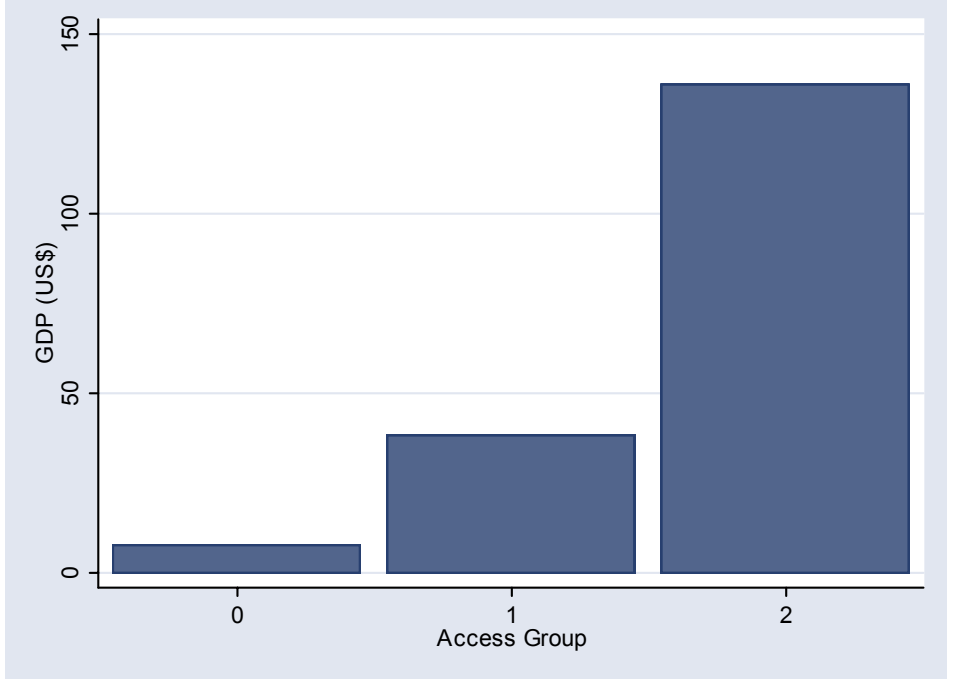

Figure 3. Access Frequency and Income Volatility

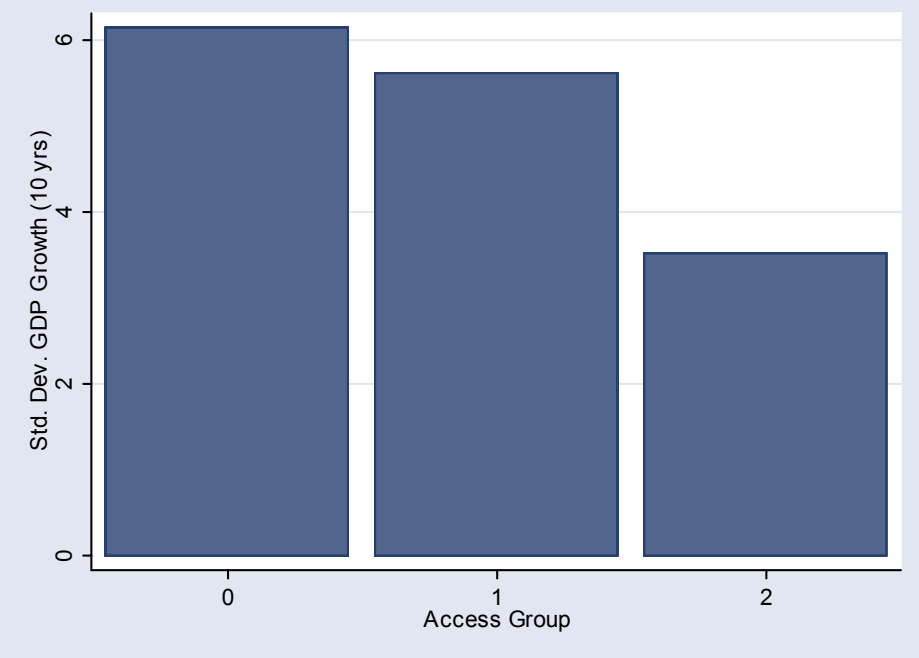

Figure 4. Access Frequency and Foreign Direct Investment as a Fraction of GDP

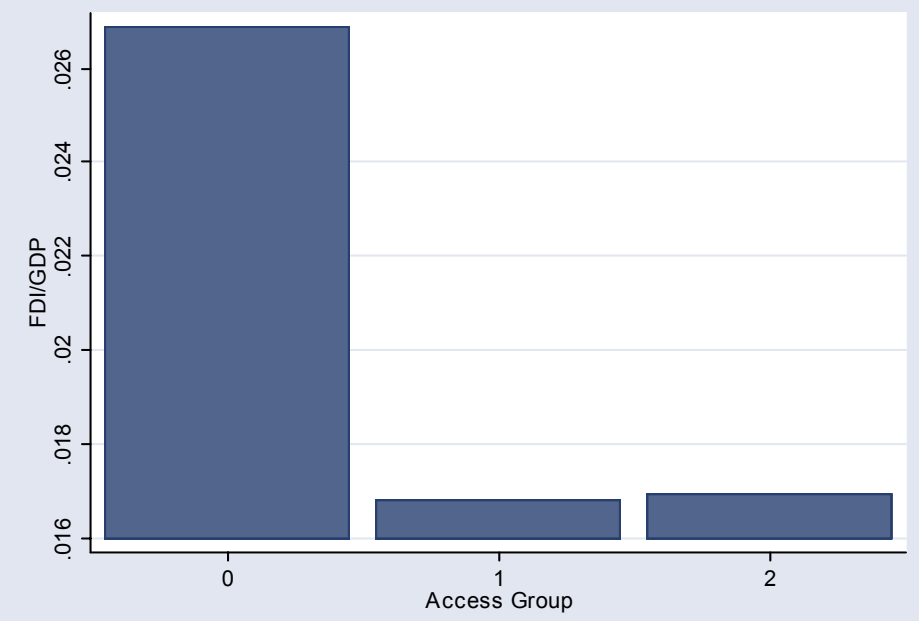

Note: Group 0: No Access, Group 1: Occasional Access, Access, Group 3: Consistent Access 
In Tobit estimations with more regressors, economic size, vulnerability, the quality of policies, and market perceptions continue to be significant (Table 3). We include GDP in all specifications and add successively variables that had entered significantly in the simple specifications in Table A4. Size (measured by GDP) is statistically significant at all conventional confidence levels in all specifications. Neither the transition nor the African dummy are consistently significant once additional control variables are included. Our measure of vulnerability, the share of agriculture in GDP, enters significantly negatively at the five percent level only if we do not control for the quality of institutions and policy. The presence of IMF SBA programs has a significant positive effect on the frequency of access in all regressions except in specification (6). The quality of institutions and policy, as measured by the World Bank's CPIA index, enters significantly in all three specifications in which it is included. ${ }^{24}$ The size of arrears as a fraction of total debt does not matter for market access once other factors are controlled for.

As for market perceptions, these can be suspected to be at least partly determined by similar variables as those included in the regression. Therefore, in order to separate the effects of those other variables from the unmeasured additional effect of market perceptions, we follow Eichengreen and Mody (1998) and Garibaldi, Mora, Sahay, and Zettelmeyer (2001) in including in the specification only the residual of a regression of market perceptions on the other variables in the regression. ${ }^{25}$ The coefficient on market perceptions is significant and strongly improves the fit of the regression. ${ }^{26}$ Of course, the interpretation of this result is difficult - after all, market perceptions must represent the unobserved factor driving market access after controlling for observable fundamentals. Nevertheless, it is interesting to be able to identify a specific rating as helpful in predicting access.

\section{B. Panel Regressions}

The previous sections highlighted the key dimensions by which frequent and infrequent accessors differ. However, these exercises do not allow us to control for time-varying factors, such as worldwide economic conditions. Moreover, they do not give us much information about what changes within countries allow countries to access the markets after periods of exclusion. More generally, simple cross-sectional comparisons are subject to various inference problems; for example, one needs to assume that any omitted country characteristics are uncorrelated with the errors.

\footnotetext{
${ }^{24}$ None of the variables except for debt entered significantly in differences.

${ }^{25}$ For a study of the determinants of such ratings, see Haque, Mark, and Mathieson (2000). We cover the main variables identified in that study in our estimations.

${ }^{26}$ From Table 2, a direct comparison of pseudo $R^{2} \mathrm{~s}$ is not possible given that the sample sizes differ across estimations. We therefore also estimated specification (5) without the market perceptions variable, obtaining a pseudo $\mathrm{R}^{2}$ of 0.66 as opposed to 0.86 when including it.
} 
Table 3. Determinants of Access Frequency (Tobit)

(Dependent variable: number of years during which capital market were accessed during 1980-2000)

\begin{tabular}{|c|c|c|c|c|c|c|c|c|}
\hline & Variable & 1 & 2 & 3 & 4 & 5 & 6 & 7 \\
\hline Size & GDP (billions US\$) & $\begin{array}{l}0.002 \\
(4.29)\end{array}$ & $\begin{array}{l}0.002 \\
(4.48)\end{array}$ & $\begin{array}{l}\mathbf{0 . 0 0 2} \\
(3.99)\end{array}$ & $\begin{array}{l}0.001 \\
(3.77)\end{array}$ & $\begin{array}{l}0.001 \\
(4.05)\end{array}$ & $\begin{array}{l}0.001 \\
(3.73)\end{array}$ & $\begin{array}{l}0.001 \\
(2.95)\end{array}$ \\
\hline $\begin{array}{l}\text { Transition } \\
\text { economies }\end{array}$ & Transition & $\begin{array}{l}0.217 \\
(1.21)\end{array}$ & $\begin{array}{l}0.202 \\
(1.21)\end{array}$ & $\begin{array}{l}0.216 \\
(1.33)\end{array}$ & $\begin{array}{l}0.155 \\
(1.10)\end{array}$ & $\begin{array}{l}0.143 \\
(1.06)\end{array}$ & $\begin{array}{l}0.100 \\
(0.74)\end{array}$ & $\begin{array}{l}-0.006 \\
(-0.04)\end{array}$ \\
\hline Africa & Sub-Saharan Africa dummy & $\begin{array}{l}-0.237 \\
(-2.93)\end{array}$ & $\begin{array}{l}-0.128 \\
(-1.63)\end{array}$ & $\begin{array}{l}-0.110 \\
(-1.38)\end{array}$ & $\begin{array}{l}-0.073 \\
(-1.07)\end{array}$ & $\begin{array}{l}-0.023 \\
(-0.34)\end{array}$ & $\begin{array}{l}-0.046 \\
(-0.73)\end{array}$ & $\begin{array}{l}-0.079 \\
(-1.22)\end{array}$ \\
\hline Vulnerability & Share of agriculture in GDP & - & $\begin{array}{l}-0.009 \\
(-3.60)\end{array}$ & $\begin{array}{l}-0.007 \\
(-2.66)\end{array}$ & $\begin{array}{l}-0.003 \\
(-1.07)\end{array}$ & $\begin{array}{c}-0.002 \\
(-0.97)\end{array}$ & $\begin{array}{l}-0.001 \\
(-0.55)\end{array}$ & $\begin{array}{l}-0.000 \\
(-0.01)\end{array}$ \\
\hline \multirow[t]{3}{*}{ IMF } & SBA & - & - & $\begin{array}{l}0.775 \\
(2.80)\end{array}$ & $\begin{array}{l}0.688 \\
(2.86)\end{array}$ & $\begin{array}{l}0.637 \\
(2.75)\end{array}$ & $\begin{array}{l}0.222 \\
(1.07)\end{array}$ & $\begin{array}{l}0.105 \\
(0.49)\end{array}$ \\
\hline & EFF & - & - & $\begin{array}{l}1.097 \\
(1.27)\end{array}$ & $\begin{array}{l}1.090 \\
(1.46)\end{array}$ & $\begin{array}{l}1.190 \\
(1.67)\end{array}$ & $\begin{array}{l}0.525 \\
(0.89)\end{array}$ & $\begin{array}{l}0.375 \\
(0.64)\end{array}$ \\
\hline & PRGF & - & - & $\begin{array}{l}-0.970 \\
(-1.27)\end{array}$ & $\begin{array}{l}-1.479 \\
(-2.23)\end{array}$ & $\begin{array}{l}-1.614 \\
(-2.55)\end{array}$ & $\begin{array}{l}-1.811 \\
(-2.93)\end{array}$ & $\begin{array}{l}-2.210 \\
(-3.45)\end{array}$ \\
\hline \multirow{2}{*}{$\begin{array}{l}\text { Productivity/ } \\
\text { quality of policies/ } \\
\text { solvency }\end{array}$} & CPIA & - & - & - & $\begin{array}{l}0.222 \\
(4.91)\end{array}$ & $\begin{array}{l}0.220 \\
(4.32)\end{array}$ & $\begin{array}{l}0.225 \\
(4.94)\end{array}$ & $\begin{array}{l}0.207 \\
(3.67)\end{array}$ \\
\hline & Arrears/Total debt & & & & & $\begin{array}{l}-0.100 \\
(-0.15)\end{array}$ & $\begin{array}{l}-0.361 \\
(-0.64)\end{array}$ & $\begin{array}{l}-0.293 \\
(-0.54)\end{array}$ \\
\hline Market perceptions & Institutional Investor Index* & - & - & - & - & & $\begin{array}{l}0.015 \\
(4.57)\end{array}$ & $\begin{array}{l}0.014 \\
(3.79)\end{array}$ \\
\hline \multirow[t]{3}{*}{ Political risk } & ICRG Index & - & - & - & - & & - & $\begin{array}{l}0.003 \\
(0.71)\end{array}$ \\
\hline & Number of observations & 140 & 135 & 135 & 130 & 123 & 87 & 78 \\
\hline & Pseudo $R^{2}$ & 0.19 & 0.29 & 0.37 & 0.53 & 0.58 & 0.92 & 1.02 \\
\hline
\end{tabular}

Source: Authors' calculations based on data from Bondware/Loanware, International Country Risk Guide (ICRG), Institutional Investor, World Bank, and IMF. Note: T-statistics are given in parentheses. Bold highlighting denotes significance at the 5 percent level. $\mathrm{A} *$ denotes the residual of a first-stage regression of the Institutional Investor Index on the other explanatory variables in the regression. SBA denotes IMF Stand-By Arrangements, EFF stands for Extended Fund Facility, and PRGF stands for Poverty Reduction and Growth Facility. CPIA stands for the World Bank's Country Policy and Institutional Assessment index.

Here, we carry out panel data estimations which should help shed further light on our questions. We experiment with pooled, random effects, and fixed effects models. Each of these techniques has its advantages and drawbacks. Pooled estimation does not allow to control for unobserved country effects. The fixed effects logit model (following Chamberlain, 1980) has the disadvantage that only countries for which we observe a switch in our dependent variable can be included in the estimation. This would discard all information contained in the sizeable group of countries that never accessed the capital market. Moreover, in fixed effects estimations one cannot assess the impact of any non-time-varying country characteristics. By contrast, a randomeffects logit model would use information from all countries in the sample. ${ }^{27}$

In the following, we will therefore center our discussion around the random-effects model. ${ }^{28}$ Wherever the results differ substantially, however, we will also refer to the other estimations, whose results are provided in the Appendix. We add time effects to all estimations

${ }^{27}$ See McKenzie (2002) for a discussion of these issues in an econometric analysis of country creditworthiness.

${ }^{28}$ Hausman specification tests do not reject the random-effect estimators. 
to control for global conditions. Except for GDP, the African and Transition dummies, and State Failures (variables which can be considered as exogenous to market access in a given year), we use lagged values of the explanatory variables to address endogeneity problems.

We first run simple logit regressions with time dummies and including one extra variable at a time in addition to the lagged stock of credit to the private sector (Appendix, Table A5). Our premise is that access is the result of changes in the binding maximum credit ceiling for a country, with the country adjusting gradually to the new maximum. In an analogy to partial adjustment models in investment, this suggests including the lagged stock of debt as a regressor.

Vulnerability (as measured by the share of agriculture in GDP, GDP per capita, or GDP volatility), IMF program dummies, the quality of policies, inflation, and market perceptions enter significantly in addition to the African and transition economy dummies. Being in Africa reduces a country's probability of accessing the markets

None of the liquidity variables turns out to be significant. Regarding solvency/productivity variables, neither export growth, GDP growth, natural resource indicators, or terms-of-trade changes affect the probability of market access. The same is true for the deviation of the real exchange rate from its five-year average or the share of FDI in GDP. Trade openness enters with a surprising negative sign. ${ }^{29}$ Default and state failures negatively affect access probability, as expected. However, the effect of defaults is weak: the probability of market access after a default is only about 3 percent lower than otherwise.

In estimations with more explanatory variables vulnerability remains consistently significant as predictor of market access. We focus again on those that were individually significant at the five percent level in simple regressions with two explanatory variables. ${ }^{30}$ Table 4 presents the results for ten different regressions. The lagged debt stock is not statistically significant in most cases. By contrast, the African dummy enters with a significant negative sign in all specifications. Similarly, our vulnerability measures (GDP per capita, the share of agriculture in GDP, and GDP volatility) have a negative, statistically significant effect on market access. In particular, GDP per capita remains significant at the one percent level in all specifications. However, quantitatively, the effect of reducing vulnerability on the probability of market access is small. After controlling for other factors, a rise in GDP per capita by US\$1,000, evaluated at mean income levels, is associated with an increase in the probability of market access by about two percent. Similarly, the decrease in GDP volatility from mean levels by one standard deviation results in a 0.6 percent higher probability of market access.

The quality of policies and institutions also clearly matter. While the coefficient on inflation is not consistently significant, our broader policy measure, the CPIA index, is. Since the

\footnotetext{
${ }^{29}$ Grigorian (2003) finds that trade openness does not affect the probability of first bond issuances.

${ }^{30}$ For space reasons, we do not show regressions with all variables that entered significantly in the simple regressions. For example, do not include GDP (which, in regressions not shown here, does not enter significantly in most specifications with many variables).
} 
CPIA index may be partly a function of the inflation, we include the residual from a regression of the CPIA index on the log of inflation in the regression. The size of the effect are nonnegligible. An increase from mean CPIA index levels to a level comparable to that of Chile in 1999 would lead to a rise in the predicted probability of access by about 9 percent.

Market perceptions (as reflected in the Institutional Investor ratings) seem to play a crucial rule; for IMF programs, the evidence is more ambiguous. The coefficient on SBA's is not significant, once the quality of policies (as measured by the CPIA) is controlled for. However, this needs to be qualified by noting that perceptions of policy and institutional quality are themselves likely to be influenced by the adoption of an IMF program. In fact, when including only the residual of the CPIA index from a regression of the index on the IMF program dummies, the coefficient on SBA programs remains significant at the five percent level and that on EFF programs at the ten percent confidence level. We cannot reach a definitive conclusion, however, since the causality could also go the other way (i.e. from policies to Fund programs). The negative effect of PRGF programs remains even after controlling for vulnerability. Market perceptions as measured by the Institutional Investor Index continue to matter, measuring something above and beyond the other factors included. ${ }^{31}$ When adding our political risk measure to specification (7), it does not enter significantly.

How good is the fit of these regressions? In order to evaluate the goodness-of-fit of our estimations, we computed the number of times the models correctly predict zeroes and ones. We use the overall in-sample probability of access of 0.22 as the cut-off point: if the model predicts a probability above 0.22 , we interpret it as predicting a " 1 " (market access). As can be seen in Table 4, with this cut-off probability, the Type I error (failure to predict access) is large initially and then drops considerably when adding explanatory variables. For example, specification (9) correctly predicts market access in 82 percent of the cases. The Type II error (failure to predict no market access) is smallest in specification 8 (11.6 percent).

Table 5 sheds more light on the question of how long it takes countries to regain market access after defaults. The median number of years it took countries to tap the markets after default fell from four years in the 1980's to zero in the 1990's. (These numbers are based on countries that had access during the year of default or in the two preceding years and regained access during the sample period; for more details, see Table A7). The decade of the eighties was of course marked by the debt crisis, an effect captured by our time dummies in the regressions. These statistics, together with the results from our panel estimations seem to contradict a common perception that defaults result in very prolonged loss of market access; they are, however, in line with the results of various studies examining the historical evidence on the costs of default. ${ }^{32}$

${ }^{31}$ Again, as in the previous section, we include the residual of the Institutional Investor rating on the other explanatory variables of the specification in the regression.

${ }^{32}$ See, for example, Eichengreen (1989), Lindert and Morton (1989), or Jorgensen and Sachs (1989). For an examination of how a country's default history matters for its crisis vulnerability, see Reinhart, Rogoff, and Savastano (2003). 
Table 4. Determinants of Access: Random-Effect Logit Model with Time Effects

\begin{tabular}{|c|c|c|c|c|c|c|c|c|c|c|}
\hline & (1) & (2) & (3) & (4) & (5) & (6) & (7) & $(8)$ & (9) & (10) \\
\hline $\begin{array}{l}\text { Public debt with } \\
\text { private credit }\end{array}$ & $\begin{array}{l}0.003 \\
(0.22)\end{array}$ & $\begin{array}{l}-0.024 \\
(2.68)^{* * *}\end{array}$ & $\begin{array}{l}0.001 \\
(0.16)\end{array}$ & $\begin{array}{l}0.002 \\
(0.21)\end{array}$ & $\begin{array}{l}0.001 \\
(0.07)\end{array}$ & $\begin{array}{l}-0.002 \\
(0.27)\end{array}$ & $\begin{array}{l}-0.004 \\
(0.50)\end{array}$ & $\begin{array}{l}-0.019 \\
(1.52)\end{array}$ & $\begin{array}{l}0.020 \\
(2.38)^{* *}\end{array}$ & $\begin{array}{l}0.014 \\
(1.24)\end{array}$ \\
\hline $\begin{array}{l}\text { Sub-Saharan } \\
\text { Africa dummy }\end{array}$ & $\begin{array}{l}-2.536 \\
(4.17)^{*} \\
* *\end{array}$ & $\begin{array}{l}-1.428 \\
(3.77)^{* * *}\end{array}$ & $\begin{array}{l}-1.298 \\
(3.58)^{* * *}\end{array}$ & $\begin{array}{l}-1.504 \\
(4.42)^{* * *}\end{array}$ & $\begin{array}{l}-1.610 \\
(4.00)^{* * *}\end{array}$ & $\begin{array}{l}-1.808 \\
(4.43)^{* * *}\end{array}$ & $\begin{array}{l}-1.901 \\
(4.73)^{* * *}\end{array}$ & $\begin{array}{l}-1.882 \\
(4.37)^{* * *}\end{array}$ & $\begin{array}{l}-2.427 \\
(4.51)^{* * *}\end{array}$ & $\begin{array}{l}-2.036 \\
(.)\end{array}$ \\
\hline Agriculture/GDP & $\begin{array}{l}-0.082 \\
(6.26)^{*} \\
* *\end{array}$ & $\begin{array}{l}-0.059 \\
(4.12)^{* * *}\end{array}$ & $\begin{array}{l}-0.061 \\
(4.06)^{* * *}\end{array}$ & $\begin{array}{l}-0.047 \\
(3.60)^{* * *}\end{array}$ & $\begin{array}{l}-0.061 \\
(3.30)^{* * *}\end{array}$ & $\begin{array}{l}-0.070 \\
(3.75)^{* * *}\end{array}$ & $\begin{array}{l}-0.072 \\
(4.03)^{* * *}\end{array}$ & $\begin{array}{l}-0.054 \\
(3.02)^{* * *}\end{array}$ & $\begin{array}{l}-0.024 \\
(1.23)\end{array}$ & $\begin{array}{l}-0.025 \\
(0.82)\end{array}$ \\
\hline GDP per capita & & $\begin{array}{l}0.001 \\
(5.03)^{* * *}\end{array}$ & $\begin{array}{l}0.001 \\
(6.01)^{* * *}\end{array}$ & $\begin{array}{l}0.001 \\
(6.69)^{* * *}\end{array}$ & $\begin{array}{l}0.000 \\
(4.42)^{* * *}\end{array}$ & $\begin{array}{l}0.000 \\
(4.15)^{* * *}\end{array}$ & $\begin{array}{l}0.000 \\
(4.13)^{* * *}\end{array}$ & $\begin{array}{l}0.000 \\
(2.34)^{* *}\end{array}$ & $\begin{array}{l}0.000 \\
(2.93)^{* * *}\end{array}$ & $\begin{array}{l}0.001 \\
(3.00)^{* * *}\end{array}$ \\
\hline $\begin{array}{l}\text { SD of GDP } \\
\text { growth (10y) }\end{array}$ & & & $\begin{array}{l}-0.084 \\
(2.18)^{* *}\end{array}$ & $\begin{array}{l}-0.183 \\
(4.39)^{* * *}\end{array}$ & $\begin{array}{l}-0.151 \\
(3.11)^{* * *}\end{array}$ & $\begin{array}{l}-0.160 \\
(3.31)^{* * *}\end{array}$ & $\begin{array}{l}-0.166 \\
(3.46)^{* * *}\end{array}$ & $\begin{array}{l}-0.048 \\
(1.14)\end{array}$ & $\begin{array}{l}-0.097 \\
(2.04)^{* *}\end{array}$ & $\begin{array}{l}-0.096 \\
(1.41)\end{array}$ \\
\hline State failure & & & & $\begin{array}{l}0.323 \\
(1.32)\end{array}$ & $\begin{array}{l}0.093 \\
(0.31)\end{array}$ & $\begin{array}{l}0.020 \\
(0.07)\end{array}$ & $\begin{array}{l}-0.018 \\
(0.07)\end{array}$ & $\begin{array}{l}0.059 \\
(0.10)\end{array}$ & $\begin{array}{l}0.091 \\
(0.27)\end{array}$ & $\begin{array}{l}0.906 \\
(1.64)\end{array}$ \\
\hline Ln inflation & & & & & $\begin{array}{l}-0.069 \\
(0.88)\end{array}$ & $\begin{array}{l}-0.067 \\
(0.89)\end{array}$ & $\begin{array}{l}-0.050 \\
(0.67)\end{array}$ & $\begin{array}{l}-0.102 \\
(0.81)\end{array}$ & $\begin{array}{l}-0.260 \\
(2.60)^{* * *}\end{array}$ & $\begin{array}{l}-0.365 \\
(2.86)^{* * *}\end{array}$ \\
\hline Default & & & & & & $\begin{array}{l}-1.483 \\
(2.47)^{* *}\end{array}$ & $\begin{array}{l}-1.548 \\
(2.60)^{* * *}\end{array}$ & $\begin{array}{l}-1.758 \\
(2.54)^{* *}\end{array}$ & $\begin{array}{l}-2.038 \\
(2.85)^{* * *}\end{array}$ & $\begin{array}{l}-1.874 \\
(1.68)^{*}\end{array}$ \\
\hline IMF SBA & & & & & & & $\begin{array}{l}-0.350 \\
(1.69)^{*}\end{array}$ & $\begin{array}{l}-0.270 \\
(1.11)\end{array}$ & $\begin{array}{l}-0.252 \\
(1.09)\end{array}$ & $\begin{array}{l}-0.078 \\
(0.27)\end{array}$ \\
\hline CPIA Index \# & & & & & & & & $\begin{array}{l}0.996 \\
(4.29)^{* * *}\end{array}$ & $\begin{array}{l}1.464 \\
(7.56)^{* * *}\end{array}$ & $\begin{array}{l}1.749 \\
(4.89)^{* * *}\end{array}$ \\
\hline $\begin{array}{l}\text { Institutional } \\
\text { Inv. Score \#\# }\end{array}$ & & & & & & & & & $\begin{array}{l}0.110 \\
(6.31)^{* * *}\end{array}$ & $\begin{array}{l}0.129 \\
(5.04)^{* * *}\end{array}$ \\
\hline ICRG Pol. Risk & & & & & & & & & & $\begin{array}{l}0.032 \\
(1.47)\end{array}$ \\
\hline Observations & 1871 & 1831 & 1754 & 1754 & 1641 & 1641 & 1641 & 1537 & 1091 & 792 \\
\hline No. of countries & 127 & 125 & 125 & 125 & 125 & 125 & 125 & 123 & 87 & 77 \\
\hline $\begin{array}{l}\text { No. of access in } \\
\text { subsample }\end{array}$ & 418 & 404 & 395 & 395 & 369 & 369 & 369 & 335 & 318 & 229 \\
\hline $\mathrm{o} / \mathrm{w}$ predicted & 280 & 182 & 200 & 248 & 237 & 248 & 247 & 153 & 263 & 187 \\
\hline $\begin{array}{l}\text { Type I error } \\
\text { (percent) }\end{array}$ & 33.0 & 54.9 & 49.4 & 37.2 & 35.8 & 32.8 & 33.1 & 54.1 & 17.3 & 18.3 \\
\hline $\begin{array}{l}\text { No. of zeroes in } \\
\text { subsample }\end{array}$ & 1453 & 1427 & 1359 & 1359 & 1272 & 1272 & 1272 & 1202 & 773 & 563 \\
\hline $\begin{array}{l}\text { o/w predicted } \\
\text { Type II error }\end{array}$ & 978 & 1183 & 1099 & 1017 & 906 & 886 & 877 & 1062 & 575 & 431 \\
\hline (percent) & 32.7 & 17.1 & 19.1 & 25.2 & 28.8 & 30.3 & 31.1 & 11.6 & 25.6 & 23.4 \\
\hline
\end{tabular}

Source: Authors' calculations based on data from IMF, Bondware/Loanware, International Country Risk Guide (ICRG), Institutional Investor, and World Bank. Note: Dependent variable is equal to one if the country issued a sovereign or publicly guaranteed bond or received a public or publicly guaranteed syndicated loan. Years of Brady deals were excluded. The regressions include time dummies (not shown). \#Residual of a regression of the CPIA index of $\ln$ (Inflation) and default. \#\#: Residual of a regression of the Institutional Investor Index on the other variables included in the regression. All explanatory variables are lagged one year. Absolute value of $\mathrm{z}$ statistics in parentheses. A* denotes significant at 10 percent; ** significant at 5 percent; *** significant at 1 percent. SBA denotes IMF Stand-By Arrangements, EFF stands for Extended Fund Facility, and PRGF stands for Poverty Reduction and Growth Facility. CPIA stands for the World Bank's Country Policy and Institutional Assessment index. 
Table 5. Default and Resumption of Access

\begin{tabular}{|c|c|c|c|c|}
\hline & $\begin{array}{c}\text { Years until } \\
\text { resumption }\end{array}$ & $\begin{array}{c}\text { Gross private capital flows (percent of GDP) } \\
\text { in 2 years prior to default }\end{array}$ & $\begin{array}{c}\text { Gross private capital flows (percent of GDP) } \\
\text { in 2 years after default }\end{array}$ \\
\hline $1980 \mathrm{~s}$ & Mean & 4.7 & 6.7 & 6.4 \\
\hline & Median & 4.0 & 5.3 & 5.8 \\
\hline $1990 \mathrm{~s}$ & Mean & 0.3 & 8.1 & 8.1 \\
\hline & Median & 0.0 & 6.5 & 9.3 \\
\hline
\end{tabular}

Note: Covers 1980-99, including only countries that had access during the year of default or in the two preceding years and regained access during the sample period. Access is defined as issuance of public or publicly guaranteed bond or syndicated loan. (Source: Bondware, Loanware). Year of default is defined as year in which the sovereign defaulted on foreign-currency bank or bond debt according to Standard \& Poor's (Source: Beers and Bhatia, 1999). Source for gross private capital flows: World Bank, World Development Indicators Data starts in 1980; for default years 1981, the data shown are numbers for 1980 instead of two-year averages. Number of defaults in 1980's included: 32. Number of defaults in 1990's included: 11. For more details, see Table A7 in the Appendix.

\section{Robustness}

\section{Substitution of private and official flows}

Do governments substitute private with official capital flows? Substitution between official and private capital flows may represent a potential problem for our approach, particularly for poor countries. During periods in which unusually large official sector financing is available, sovereigns may purposely abstain from tapping private capital markets, and the corresponding zero in our binary variable would not reflect a binding credit constraint. In order to investigate this possibility, we computed the mean of official finance flows as percentage of GDP over time. We then asked whether during (or immediately following) periods of higher-than-average official flows, our access variable is more likely to show a zero. This is not the case. On the contrary, it is more likely to observe a zero, when official flows are below normal (Table 6). A different way of looking at this issue is regressing the volume of private capital flows on official flows (as shares of GDP). Such a regression with fixed country effects and time effects produces a positive and statistically significant coefficient on the official financing variable ( $\mathrm{t}$-statistic $=$ 3.07), indicating that, if anything, there is complementarity between official and private flows.

Table 6. Relation between Official Flows and Probability of Observing No Access

\begin{tabular}{|l|c|}
\hline & \# of zeroes \\
\hline Official flows $>$ country average & 677 \\
\hline Official flows $<$ country average & 862 \\
\hline $\begin{array}{l}\text { Lagged official flows }<\text { country } \\
\text { average }\end{array}$ & 743 \\
\hline $\begin{array}{l}\text { Lagged official flows }<\text { country } \\
\text { average }\end{array}$ & 796 \\
\hline
\end{tabular}


Similarly, when including the lagged deviation of net official flows from the country mean in a random-effect logit regression similar to those in Table A4, the coefficient is insignificant, while it is positive and significant ( $\mathrm{t}$-statistic $=2.07$ ) if the variable is included contemporaneously.

\section{Fixed effects}

The main results remain unaltered when using fixed instead of random effects (Appendix, Table A6). The importance of policies increases somewhat; the inflation variable is now significant in all cases where it is included and has larger coefficients. The standard deviation of GDP growth looses statistical significance; this is to be expected, since the fixed effects absorb most of the country characteristics that change slowly over time. The results for IMF SBA programs are unchanged.

\section{State dependence}

There are two reasons why a country that has had market access yesterday may be more likely to gain market access today. First, countries might differ in certain characteristics that persist over time. Alternatively, it is possible that gaining market access at some point per se fundamentally changes the likelihood of the country to tap the markets again. This is sometimes referred to as the difference between "spurious" and "true" state dependence (Heckman, 1981).

Testing for the difference between spurious and true state dependence is not trivial in the presence of heterogeneity. Chamberlain (1978) suggested a simple test of the null of no state dependence by testing whether the including lagged independent variables without including lagged dependent variables significantly changes the probability of the event. (see also Hsiao, 1986, and McKenzie, 2002). We carried out this test, and the results varied somewhat depending on the exact specification. For this reason, we also carried out estimations that allow for state dependence by including a lagged dependent variable (not shown).

While in these estimations, the coefficient on the lagged dependent variable is always significant, the other main results are not changed. The main difference is that inflation looses its statistical significance in three out of four cases. Market perceptions also become somewhat less important. The predictive power of the regression improves somewhat through the inclusion of the lagged dependent variable.

\section{Aggregating over two years}

While it is unlikely that a developing country would want to voluntarily abstain from any form of sovereign borrowing over the course of a full year, such an abstention is even less likely over a two-year period. We therefore also run regressions aggregating the data over two years (not shown). The results are very similar. 


\section{Conclusions}

Our analysis revealed six regularities that are robust to estimation techniques:

(1) The perceived quality of policies and institutions matters substantially. In addition, the Institutional Investor Index captures well the additional element of "market perceptions" which extends beyond simple measurable country characteristics.

(2) Countries that are more vulnerable to shocks are less likely to tap international credit markets.

(3) Standard liquidity indicators such as reserve coverage do no help in predicting market access; the same is true for most standard indicators of macroeconomic policies, except inflation.

(4) Contrary to predictions from the theory of sovereign borrowing, a country's links with the rest of the world (such as FDI or trade openness) do not increase market access.

(5) Once the perceived quality of policies is controlled for, we do not find an catalytic effect of IMF SBA or EFF programs. This has to be qualified by the fact that the perceptions of policies themselves are likely to be affected by the presence of an IMF program. By contrast, PRGF programs negatively affect the probability of market access.

(6) The probability of market access is not strongly influenced by a default in the previous year. In the 1990s, on average, countries that defaulted did not experience interruptions in their market access.

Further work should examine these results in more detail, complementing our crosscountry approach with case studies. Finally, we should end with a reminder that our work is entirely positive, not normative. In other words, we do not discuss the broader question of whether it is per se desirable for developing countries to substantially increase sovereign borrowing. ${ }^{33}$

${ }^{33}$ Reinhart, Rogoff, and Savastano (2003) show that many developing countries experience extreme duress at debt levels that would seem manageable by advanced country standards. 


\section{APPENDIX}

\section{GDP}

For GDP in current U.S. dollars, as for all other macroeconomic variables, we use data from the World Bank's World Development Indicators database (WDI). We complete the WDI series, when possible ${ }^{34}$ with data from the IMF's World Economic Outlook (WEO) database and data from IMF country desks.

\section{Productivity/solvency}

To capture the macroeconomic situation, we include GDP growth and inflation. We account for the existence of natural resources such as mines and fuel reserves by looking at mining and quarries and as well as the share of fuel production in exports. In order to further measure the quality of government policies and institutions, we use yearly data from the World Bank's Country Policy and Institutional Assessment database (CPIA). The index summarizes assessments on twenty scores in the areas of economic management, structural policies, policies for social inclusion, and public sector management and institutions. To capture the size of the financial sector, we use the ratio of M2 to GDP. Wars and civil conflicts obviously adversely affect a country's productivity, and we construct a war dummy variable based on data from the KOSIMO (2003) website to account for conflicts; since there are many cases of minor conflicts, we only set this dummy variable equal to one if the conflict produced at least 1,000 casualties. We also use the data set on "State Failures" from the State Failure Task Force (http://www.cidcm.umd.edu/inscr/stfail/): we construct a dummy which equals one in the case of civil wars, major regime transitions, breakdowns of social order, or major ethnic conflicts. Other variables that we use to measuring the solvency of a country are (in addition to total debt) interest payments, international reserves in months of imports, and the ratio of debt service to exports.

\section{Political stability}

In order to measure political instability, we use the International Country Risk Guide's index of political risk.

\section{Links to the world}

The ratio of FDI to GDP and the traditional measure of trade openness (the sum of exports and imports divided by GDP) try to capture the potential cost of sanctions or reputation spillovers.

\section{GDP volatility and vulnerability to shocks}

To measure a country's vulnerability to shocks, we include the share of agriculture in GDP, the standard deviation of GDP growth (measured as a 10-year moving average), GDP per capita, and the standard deviation of the terms-of-trade (20-year moving average). Good terms-

\footnotetext{
${ }^{34}$ We checked the consistency of the series from the different sources, combining the series only when they were consistent.
} 
of-trade data are hard to come by. Here, we use a comprehensive, high-quality database compiled by Cashin and Pattillo (2000), which is largely based on World Bank data.

\section{Existing debt stock and default}

We use data on the total existing debt stock from the World Bank's Global Development Finance Database (GDF). We define default as an event in which there was a default by sovereigns on foreign-currency non-official bond or bank debt, as defined by Standard \& Poor's and reported in Beers and Bhatia (1999). Standard \& Poor's consider as a default any missed payment or a renegotiation with a reduction in the net preset value of the debt.

\section{World factors}

We control for the global environment using time effects in the estimation. Alternatively, we explicitly include the 6 months LIBOR in real terms, the average GDP growth rate for the G7 countries and total flows of bonds and bank loans to the public sector of developing countries.

\section{IMF programs}

IMF programs should be expected to have a catalytic effect for capital flows. ${ }^{35} \mathrm{We}$ differentiate between three types of programs: Stand-By Arrangements (SBAs), Extended Fund Facilities (EFFs), and Poverty Reduction and Growth Facilities (PRGFs). SBA's are usually one to two-year programs. EFFs are economic programs that generally run for three years and are aimed at overcoming balance of payments difficulties resulting from macroeconomic and structural problems. PRGFs were originally established as the Enhanced Structural Adjustment Facility (ESAF) in 1987, enlarged and extended in 1994, and further strengthened in 1999 to make poverty reduction a key and more explicit element. The purpose of the facility is to support programs to strengthen balance of payments positions, and to foster durable growth, leading to poverty reduction. Eighty low-income countries are currently PRGF-eligible. Loans are disbursed under three-year arrangements. Conditions are concessional. PRGF-supported programs contain strict limits on private capital borrowing. We experiment both with dummies that are equal to one throughout the duration of the program and dummies that are set to one only at the beginning year of the program.

\section{Transition economies}

To account for the fact that the newly opened former communist economies had specific characteristics that differentiated them from other economies, we create a dummy variable which is equal to one for transition economies after their opening up or newly found independence.

\section{Market perceptions}

To measure market perceptions, we use the annual average of the biannual country rating published Institutional Investor. These ratings are based on assessments obtained from the staffs of about 100 large commercial banks. Ratings are given on a range from zero to 100, where 100 represents the smallest probability of default.

${ }^{35}$ See Mody and Saravia (2003) for a careful examination of this issue. 
Table A1. Date of Inclusion of Formerly Centrally Planned Economies

\begin{tabular}{|c|c|}
\hline Country & Date of Inclusion in Sample \\
\hline Albania & 1990 \\
\hline Armenia & 1991 \\
\hline Azerbaijan & 1991 \\
\hline Belarus & 1991 \\
\hline Bosnia and Herzegovina & 1992 \\
\hline Bulgaria & 1985 \\
\hline Burkina Faso & 1991 \\
\hline Cape Verde & 1991 \\
\hline China & 1982 \\
\hline Congo, Rep. of & 1989 \\
\hline Croatia & 1991 \\
\hline Czech Republic & 1993 \\
\hline Egypt & 1980 \\
\hline Eritrea & 1992 \\
\hline Estonia & 1991 \\
\hline Georgia & 1991 \\
\hline Guinea-Bissau & 1985 \\
\hline Guyana & 1992 \\
\hline Hungary & 1980 \\
\hline Kazakhstan & 1991 \\
\hline Kyrgyz Republic & 1991 \\
\hline Lao PDR & 1992 \\
\hline Latvia & 1991 \\
\hline Lithuania & 1991 \\
\hline Macedonia, FYR & 1992 \\
\hline Madagascar & 1993 \\
\hline Mali & 1992 \\
\hline Moldova & 1991 \\
\hline Mongolia & 1990 \\
\hline Poland & 1980 \\
\hline Romania & 1980 \\
\hline Russian Federation & 1991 \\
\hline Rwanda & 1989 \\
\hline Seychelles & 1992 \\
\hline Slovak Republic & 1993 \\
\hline Slovenia & 1991 \\
\hline Somalia & 1990 \\
\hline Syria & 1983 \\
\hline Tajikistan & 1991 \\
\hline Togo & 1990 \\
\hline Turkmenistan & 1991 \\
\hline Ukraine & 1991 \\
\hline Uzbekistan & 1991 \\
\hline Vietnam & 1986 \\
\hline Zambia & 1990 \\
\hline
\end{tabular}


Table A2. Market Access, by Country

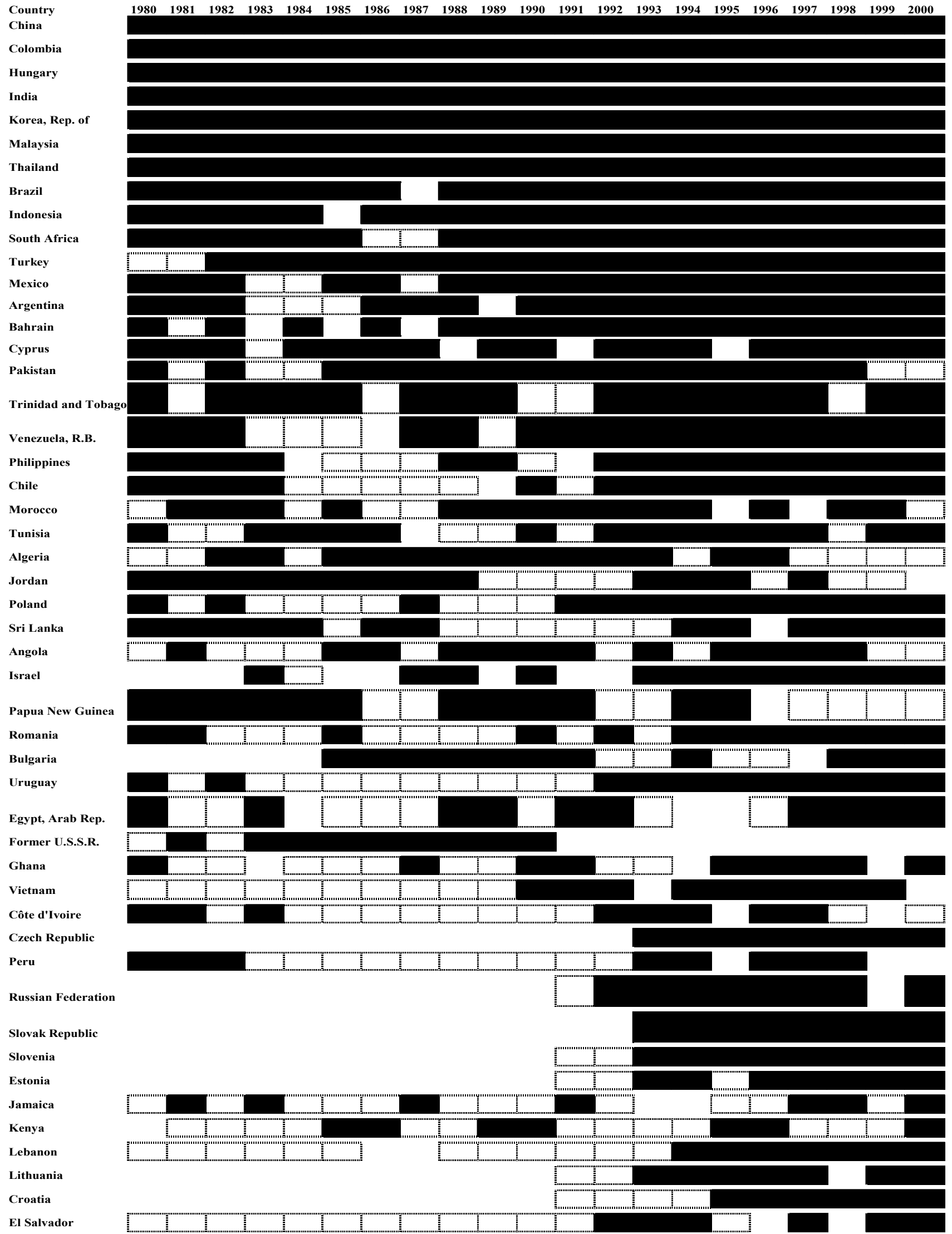


Table 2. Market Access, by Country (continued)

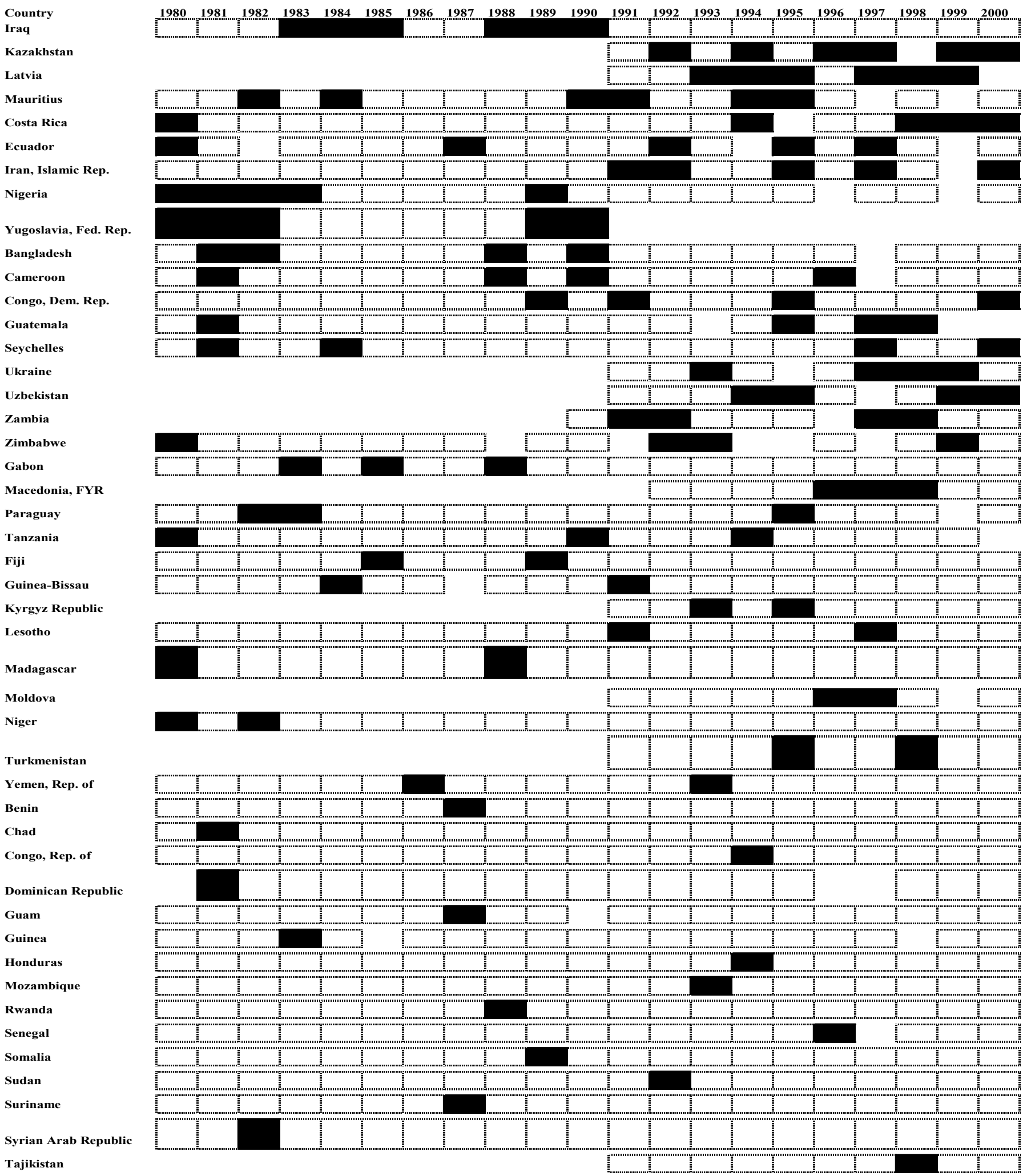


Table A2. Market Access, by Country (concluded)

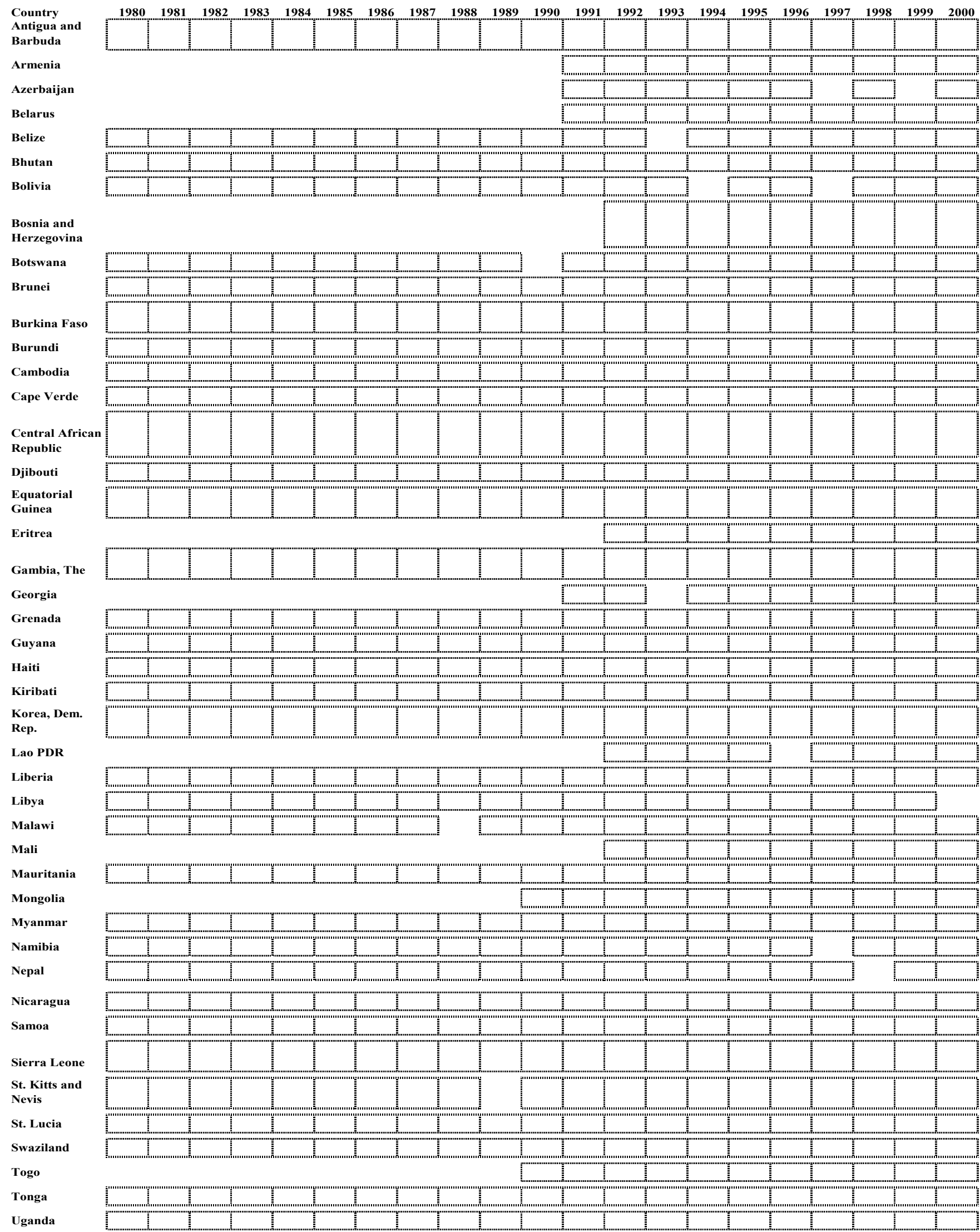


Table A3. Tests of Equality of Means and Medians Across Groups

\begin{tabular}{|c|c|c|c|c|c|c|c|}
\hline & & \multicolumn{3}{|c|}{ Mean (Welch test) } & \multicolumn{3}{|c|}{ Median } \\
\hline & & $0-1$ & $1-3$ & $0-3$ & $0-1$ & $1-3$ & $0-3$ \\
\hline Size & GDP (billion U.S. dollars) & $* *$ & $*$ & $* *$ & $* *$ & & $* *$ \\
\hline \multirow{3}{*}{$\begin{array}{l}\text { Debt/ } \\
\text { Liquidity }\end{array}$} & Total Debt 1981/GDP & & $* *$ & $* *$ & & $* *$ & \\
\hline & Exports/Debt service & & $* *$ & $* *$ & $* *$ & & $* *$ \\
\hline & Reserves/months ofimports & & & $*$ & & $*$ & $* *$ \\
\hline \multirow{4}{*}{ Vulnerability } & GDP per capita (U.S. dollars) & & & & $* *$ & & \\
\hline & Agriculture/GDP (percent) & $* *$ & & $* *$ & $* *$ & & $* *$ \\
\hline & Standard deviation of GDP growth & & $* *$ & $* *$ & & $* *$ & $* *$ \\
\hline & Standard deviation of terms of trade & * & $* *$ & $* *$ & $* *$ & & $* *$ \\
\hline \multirow{9}{*}{$\begin{array}{l}\text { Productivity/ } \\
\text { solvency/quality } \\
\text { of policies }\end{array}$} & GDP growth (percent) & & $* *$ & $* *$ & * & $* *$ & \\
\hline & Mining/GDP & & & & & & \\
\hline & Fuel exports/GDP & & & & $* *$ & & $* *$ \\
\hline & Export growth & & & & & $*$ & $*$ \\
\hline & Inflation (percent) & & $* *$ & $* *$ & $* *$ & * & \\
\hline & Fiscal deficit/GDP & & & & & & $* *$ \\
\hline & Arrears/total debt & & $* *$ & $* *$ & & $* *$ & $* *$ \\
\hline & CPIA & $* *$ & $* *$ & $* *$ & $* *$ & $* *$ & $* *$ \\
\hline & "State Failures" & & & & & & \\
\hline \multirow{2}{*}{ Links } & FDI/GDP & & & & & & \\
\hline & Openness (Exp.+ Imp./GDP) & $*$ & & & & & \\
\hline Political risk & ICRG Political Risk Index & $*$ & * & $* *$ & $* *$ & & $*$ \\
\hline Market perceptions & Institutional Investor Rating & $* *$ & $* *$ & $* *$ & $* *$ & $* *$ & $* *$ \\
\hline \multirow{3}{*}{ IMF } & SBA & $* *$ & & & $* *$ & & \\
\hline & EFF & $* *$ & $* *$ & & $* *$ & & \\
\hline & PRGF & $* *$ & $* *$ & $* *$ & $* *$ & * & $* *$ \\
\hline
\end{tabular}

Sources: Authors' calculations based on data from IMF, World Bank, Institutional Investor, International Country Risk Guide (ICRG), and Bondware/Loanware.

Note: $\mathrm{A} *$ stands for statistical significance at the 10 percent level, $* *$ stands for statistical significance at the 5 percent level. SBA denotes IMF Stand-By Arrangements, EFF stands for Extended Fund Facility, and PRGF stands for Poverty Reduction and Growth Facility. FDI stands for Foreign Direct Investment. CPIA stands for the World Bank's Country Policy and Institutional Assessment. 


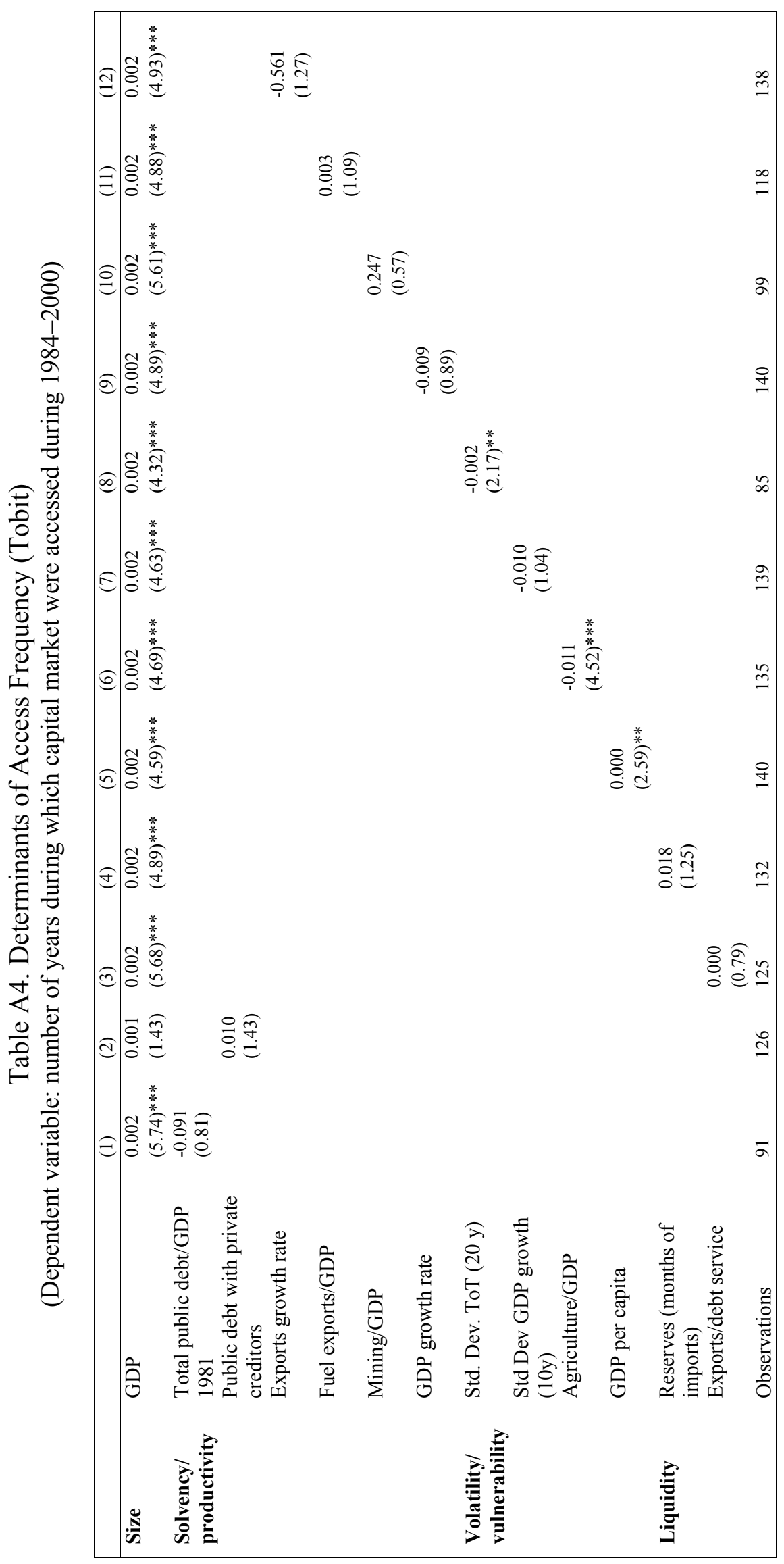




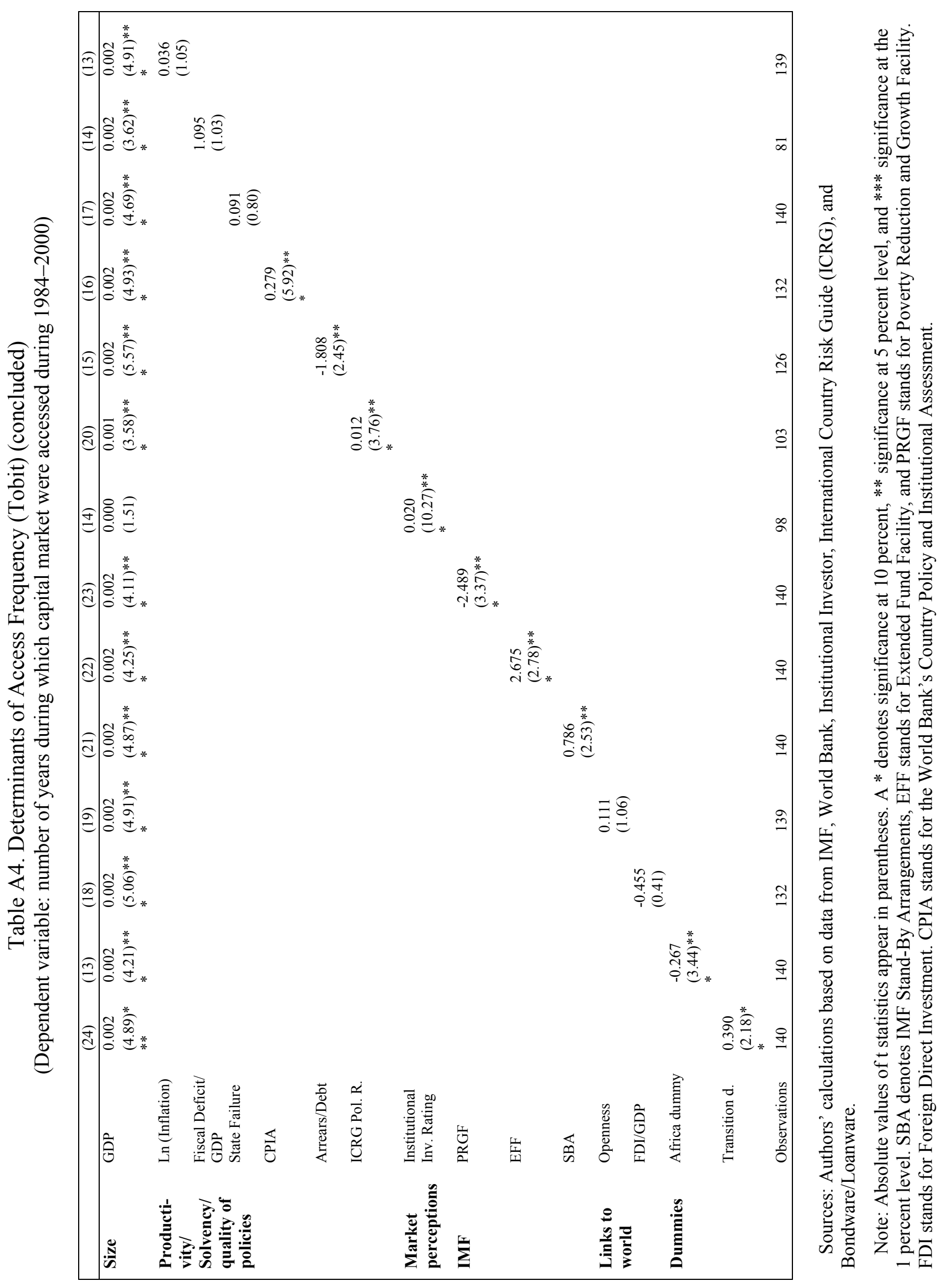




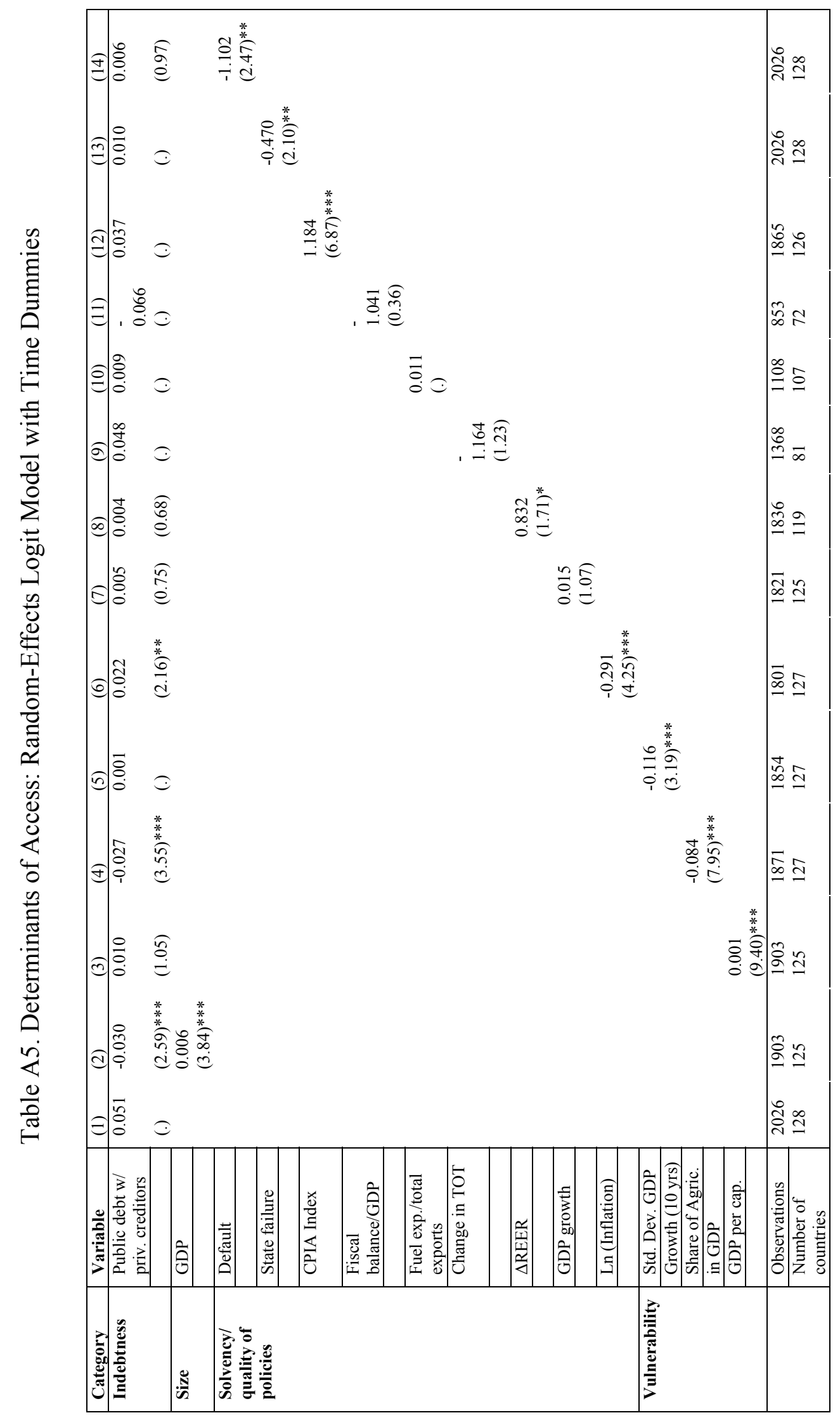




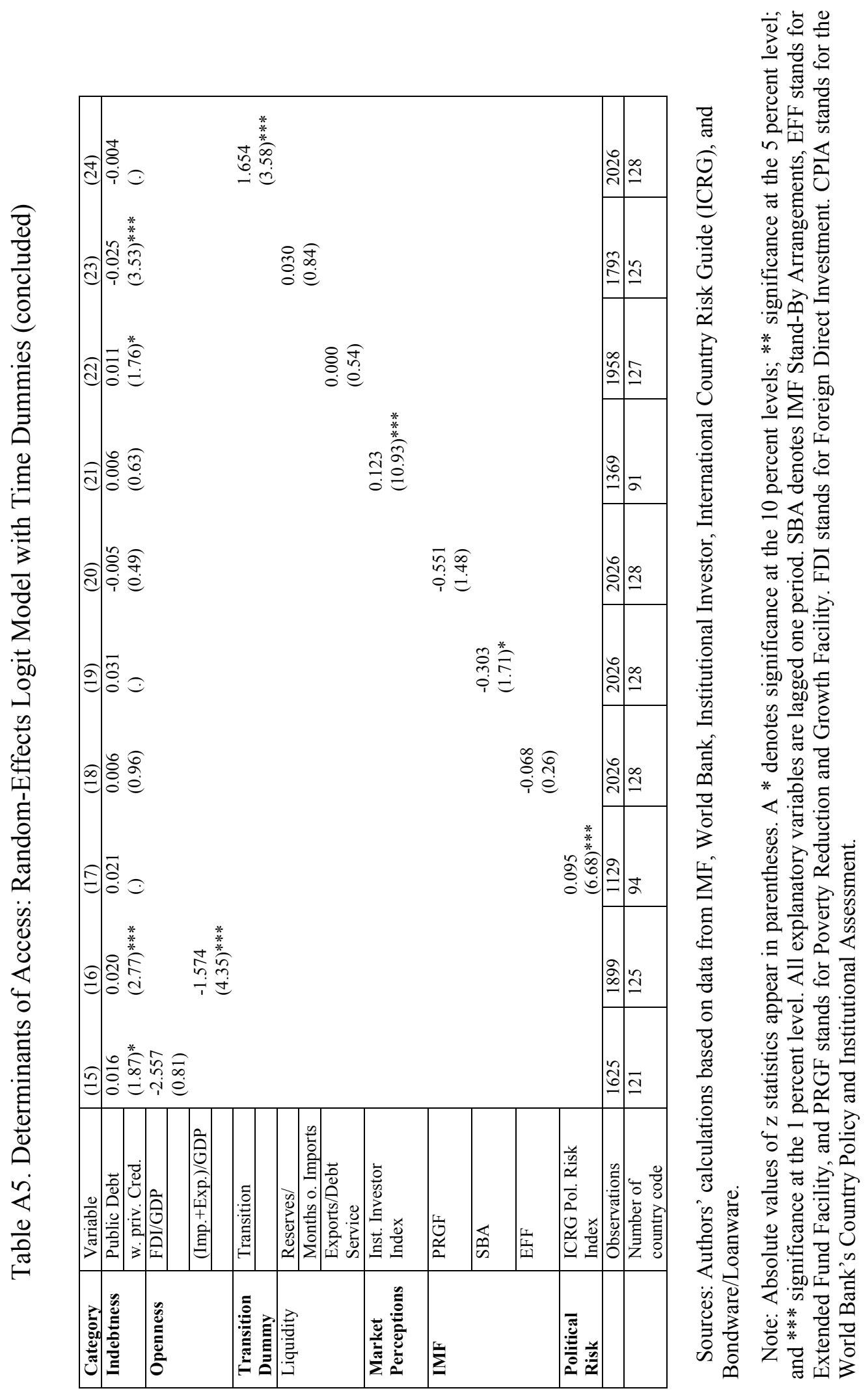


Table A6. Determinants of Access: Fixed-Effect Logit Model with Time Dummies

\begin{tabular}{|c|c|c|c|c|c|c|c|c|c|c|}
\hline & $(1)$ & $(2)$ & (3) & $(4)$ & $(5)$ & $(6)$ & $(7)$ & $(8)$ & $(9)$ & $(10)$ \\
\hline $\begin{array}{l}\text { Publ. debt w/ } \\
\text { private credit }\end{array}$ & $\begin{array}{l}-0.056 \\
(2.85) \\
* * *\end{array}$ & $\begin{array}{l}-0.062 \\
(2.95)^{* *} \\
*\end{array}$ & $\begin{array}{l}-0.051 \\
(2.41)^{* *}\end{array}$ & $\begin{array}{l}-0.052 \\
(2.41)^{* *}\end{array}$ & $\begin{array}{l}-0.059 \\
(2.32)^{* *}\end{array}$ & $\begin{array}{l}-0.065 \\
(2.48)^{* *}\end{array}$ & $\begin{array}{l}-0.060 \\
(2.33)^{* *}\end{array}$ & $\begin{array}{l}-0.065 \\
(2.32)^{* *}\end{array}$ & $\begin{array}{l}-0.024 \\
(0.81)\end{array}$ & $\begin{array}{l}-0.149 \\
(2.34)^{* *}\end{array}$ \\
\hline Agric/GDP & $\begin{array}{l}-0.071 \\
(3.01) \\
* * *\end{array}$ & $\begin{array}{l}-0.056 \\
(2.32)^{* *}\end{array}$ & $\begin{array}{l}-0.045 \\
(1.81)^{*}\end{array}$ & $\begin{array}{l}-0.043 \\
(1.71)^{*}\end{array}$ & $\begin{array}{l}-0.035 \\
(1.32)\end{array}$ & $\begin{array}{l}-0.036 \\
(1.35)\end{array}$ & $\begin{array}{l}-0.039 \\
(1.46)\end{array}$ & $\begin{array}{l}-0.037 \\
(1.19)\end{array}$ & $\begin{array}{l}-0.029 \\
(0.80)\end{array}$ & $\begin{array}{l}-0.024 \\
(0.40)\end{array}$ \\
\hline GDP p/ capita & & $\begin{array}{l}0.001 \\
(5.29)^{* *} \\
*\end{array}$ & $\begin{array}{l}0.001 \\
(5.01)^{* *} \\
*\end{array}$ & $\begin{array}{l}0.001 \\
(4.99)^{* *} \\
*\end{array}$ & $\begin{array}{l}0.000 \\
(3.36)^{* *} \\
*\end{array}$ & $\begin{array}{l}0.000 \\
(3.19)^{* *} \\
*\end{array}$ & $\begin{array}{l}0.000 \\
(3.07)^{* *} \\
*\end{array}$ & $\begin{array}{l}0.000 \\
(2.84)^{* *} \\
*\end{array}$ & $\begin{array}{l}0.000 \\
(1.73)^{*}\end{array}$ & $\begin{array}{l}0.001 \\
(2.31)^{* *}\end{array}$ \\
\hline $\begin{array}{l}\text { SD of GDP } \\
\text { growth (10y) }\end{array}$ & & & $\begin{array}{l}-0.134 \\
(2.41)^{* *}\end{array}$ & $\begin{array}{l}-0.132 \\
(2.37)^{* *}\end{array}$ & $\begin{array}{l}-0.118 \\
(2.01)^{* *}\end{array}$ & $\begin{array}{l}-0.112 \\
(1.91)^{*}\end{array}$ & $\begin{array}{l}-0.114 \\
(1.94)^{*}\end{array}$ & $\begin{array}{l}-0.087 \\
(1.36)\end{array}$ & $\begin{array}{l}-0.096 \\
(1.32)\end{array}$ & $\begin{array}{l}-0.186 \\
(1.44)\end{array}$ \\
\hline State failure & & & & $\begin{array}{l}-0.160 \\
(0.48)\end{array}$ & $\begin{array}{l}-0.349 \\
(0.98)\end{array}$ & $\begin{array}{l}-0.353 \\
(0.97)\end{array}$ & $\begin{array}{l}-0.303 \\
(0.83)\end{array}$ & $\begin{array}{l}-0.029 \\
(0.07)\end{array}$ & $\begin{array}{l}0.173 \\
(0.37)\end{array}$ & $\begin{array}{l}0.158 \\
(0.19)\end{array}$ \\
\hline Ln inflation & & & & & $\begin{array}{l}-0.174 \\
(1.96)^{* *}\end{array}$ & $\begin{array}{l}-0.177 \\
(1.98)^{* *}\end{array}$ & $\begin{array}{l}-0.157 \\
(1.73)^{*}\end{array}$ & $\begin{array}{l}-0.287 \\
(2.52)^{* *}\end{array}$ & $\begin{array}{l}-0.441 \\
(3.45)^{* *} \\
*\end{array}$ & $\begin{array}{l}-0.546 \\
(2.98)^{* *} \\
*\end{array}$ \\
\hline Default & & & & & & $\begin{array}{l}-1.487 \\
(2.39) * *\end{array}$ & $\begin{array}{l}-1.560 \\
(2.49)^{* *}\end{array}$ & $\begin{array}{l}-1.830 \\
(2.57)^{* *}\end{array}$ & $\begin{array}{l}-2.205 \\
(2.79)^{* *} \\
*\end{array}$ & $\begin{array}{l}-1.012 \\
(0.92)\end{array}$ \\
\hline IMF SBA & & & & & & & $\begin{array}{l}-0.366 \\
(1.63)\end{array}$ & $\begin{array}{l}-0.306 \\
(1.25)\end{array}$ & $\begin{array}{l}-0.290 \\
(1.11)\end{array}$ & $\begin{array}{l}0.102 \\
(0.31)\end{array}$ \\
\hline CPIA Index \# & & & & & & & & $\begin{array}{l}0.955 \\
(4.75) * * \\
*\end{array}$ & $\begin{array}{l}1.501 \\
(5.90)^{* *} \\
*\end{array}$ & $\begin{array}{l}1.868 \\
(4.60)^{* *} \\
*\end{array}$ \\
\hline $\begin{array}{l}\text { Institutional } \\
\text { Investor Score }\end{array}$ & & & & & & & & & $\begin{array}{l}0.094 \\
(4.23)^{* *} \\
*\end{array}$ & $\begin{array}{l}0.157 \\
(3.76)^{* *} \\
*\end{array}$ \\
\hline ICRG & & & & & & & & & & $\begin{array}{l}0.026 \\
(1.06)\end{array}$ \\
\hline No. of obs. & 1,051 & 1,031 & 996 & 996 & 897 & 897 & 897 & 806 & 727 & 493 \\
\hline $\begin{array}{l}\text { No. of } \\
\text { countries }\end{array}$ & 68 & 67 & 65 & 65 & 62 & 62 & 62 & 58 & 52 & 41 \\
\hline $\begin{array}{l}\text { No. of access } \\
\text { in subsample }\end{array}$ & 418 & 404 & 395 & 395 & 369 & 369 & 369 & 335 & 318 & 229 \\
\hline $\mathrm{O} / \mathrm{w}$ predicted & 5 & 7 & 10 & 11 & 17 & 20 & 24 & 43 & 37 & 43 \\
\hline $\begin{array}{l}\text { Type I error } \\
\text { (percent) }\end{array}$ & 98.8 & 98.3 & 97.5 & 97.2 & 95.4 & 94.6 & 93.5 & 87.2 & 88.4 & 81.2 \\
\hline $\begin{array}{l}\text { No. of zeroes } \\
\text { in subsample }\end{array}$ & 1,453 & 1,427 & 1,359 & 1,359 & 1,272 & 1,272 & 1,272 & 1,202 & 773 & 563 \\
\hline $\mathrm{O} / \mathrm{w}$ predicted & 1,440 & 1,416 & 1,341 & 1,341 & 1,247 & 1,245 & 1,244 & 1,150 & 741 & 520 \\
\hline $\begin{array}{l}\text { Type II error } \\
\text { (percent) }\end{array}$ & 0.9 & 0.8 & 1.3 & 1.3 & 2.0 & 2.1 & 2.2 & 4.3 & 4.1 & 7.6 \\
\hline
\end{tabular}

Sources: Authors' calculations based on data from IMF, World Bank, Institutional Investor, International Country Risk Guide (ICRG), and Bondware/Loanware.

Note: Dependent variable is equal to one if the country issued a sovereign or publicly guaranteed bond or received a public or publicly guaranteed syndicated loan. Years of Brady deals were excluded. The regressions include time dummies (not shown). A \# denotes the residual of a regression of the CPIA index of $\ln$ (Inflation) and default. A \#\# denotes the residual of a regression of the Institutional Investor Index on the other variables included in the regression. All explanatory variables are lagged one year. SBA denotes IMF Stand-By Arrangements, EFF stands for Extended Fund Facility, and PRGF stands for Poverty Reduction and Growth Facility. CPIA stands for the World Bank's Country Policy and Institutional Assessment. The symbols *, **, *** denote significance at the 10, 5 , and 1 percent level, respectively. 
Table A7. Default and Resumption of Access

\begin{tabular}{|c|c|c|c|c|c|}
\hline $\begin{array}{c}\text { Year of Default } \\
(1980 s-1990 s) \\
1980 s \\
\end{array}$ & $\begin{array}{c}\text { Year of } \\
\text { Resumption }\end{array}$ & Country & $\begin{array}{l}\text { Years Until } \\
\text { Resumption }\end{array}$ & $\begin{array}{c}\text { Private Gross Capital } \\
\text { Flows as Percent of GDP } \\
\text { in Two Years Prior to } \\
\text { Default }\end{array}$ & $\begin{array}{l}\text { Private Gross Capital } \\
\text { Flows as Percent of } \\
\text { GDP in Two Years } \\
\text { After Resumption }\end{array}$ \\
\hline 1980 & 1980 & Peru & 0 & $\ldots$ & 1.3 \\
\hline 1981,84 & 1994 & Costa Rica & 13 & 19.3 & 8.0 \\
\hline 1981 & 1994 & Honduras & 13 & 9.7 & 4.7 \\
\hline 1981 & 1983 & Jamaica & 2 & 8.0 & 8.8 \\
\hline 1981 & 1988 & Madagascar & 7 & 0.2 & 1.7 \\
\hline 1981 & 1982 & Poland & 1 & $\ldots$ & $\ldots$ \\
\hline 1981 & 1985 & Romania & 14 & $\ldots$ & $\ldots$ \\
\hline 1982 & 1986 & Argentina & 4 & 19.9 & 1.8 \\
\hline 1982 & 1987 & Ecuador & 5 & 6.4 & 3.6 \\
\hline 1982 & 1985 & Mexico & 3 & 8.5 & 10.6 \\
\hline 1982 & 1989 & Nigeria & 7 & 1.7 & 7.9 \\
\hline 1982 & 1982 & Turkey & 0 & 2.0 & 1.4 \\
\hline 1983 & 1983 & Brazil & 0 & 4.5 & 4.3 \\
\hline 1983 & 1990 & Chile & 7 & 14.5 & 12.8 \\
\hline 1983 & 1992 & Côte d'Ivoire & 9 & 4.2 & 5.9 \\
\hline 1983 & 1985 & Morocco & 2 & 3.6 & 4.1 \\
\hline 1983 & 1983 & Niger & 0 & 8.4 & $\ldots$ \\
\hline 1983 & 1993 & Peru & 9 & 3.7 & 8.7 \\
\hline 1983 & 1988 & Philippines & 5 & 5.7 & 5.7 \\
\hline 1983 & 1992 & Uruguay & 9 & 9.9 & 7.2 \\
\hline 1983 & 1987 & Venezuela, R.B. & 12 & 8.7 & 8.4 \\
\hline 1984 & 1988 & Egypt, Arab Rep. & 4 & 4.3 & 7.6 \\
\hline 1985 & 1988 & South Africa & 3 & 2.1 & 3.0 \\
\hline 1986 & 1988 & Gabon & 2 & 15.1 & 13.4 \\
\hline 1986 & 1988 & Morocco & 2 & 3.2 & 4.0 \\
\hline 1986 & 1990 & Romania & 4 & $\ldots$ & 3.5 \\
\hline 1987 & 1990 & Ghana & 3 & 2.0 & 2.0 \\
\hline 1987 & 1988 & Iraq & 1 & $\ldots$ & $\ldots$ \\
\hline \multirow[t]{2}{*}{1988} & 1992 & Trinidad and & & & \\
\hline & & Tobago & 4 & 5.7 & 12.6 \\
\hline 1989 & 1989 & Argentina & 0 & 2.6 & 11.2 \\
\hline 1989 & 1993 & Jordan & 4 & 5.3 & 12.0 \\
\hline \multirow[t]{2}{*}{1989} & 1989 & South Africa & 0 & 2.9 & 2.7 \\
\hline & & Mean & 4.7 & 6.7 & 6.4 \\
\hline 1990s & & Median & 4.0 & 5.3 & 5.8 \\
\hline 1991 & 1991 & Algeria & 0 & 2.2 & 3.2 \\
\hline 1991 & 1992 & Ethiopia & 1 & 2.0 & 4.3 \\
\hline 1991 & 1992 & Russian Federation & 1 & $\ldots$ & $\ldots$ \\
\hline 1992 & 1992 & Philippines & 0 & 5.6 & 10.7 \\
\hline 1993 & 1993 & South Africa & 0 & 5.9 & 5.3 \\
\hline 1995 & 1995 & Venezuela, RB & 0 & 14.3 & 10.7 \\
\hline 1998 & 1998 & Indonesia & 0 & 6.5 & 9.3 \\
\hline 1998 & 1998 & Ukraine & 0 & 8.4 & 13.3 \\
\hline 1998 & 2000 & Russian Federation & $1 *$ & 14.3 & $14.7 * *$ \\
\hline \multirow[t]{3}{*}{1999} & 2000 & Ecuador & 1 & 14.1 & $31.4 * *$ \\
\hline & & Mean: & 0.3 & 8.1 & 8.1 \\
\hline & & Median: & $\mathbf{0 . 0}$ & 6.5 & 9.3 \\
\hline
\end{tabular}

Sources: Beers and Bhatia (1999) and authors' calculation based on data from the World Bank.

Note: Covers 1980-99, including only countries that had access in the two years prior to the default or in the default year and that regained access until 2000. (The following countries had access during the year of default or in the two preceding years and never resumed access in the sample period: Dominican Republic (1982), Guinea (1986), Moldova (1998), Niger (1983), and Pakistan (1998).) Access is defined as issuance of public or publicly guaranteed bond or syndicated loan. (Source: Bondware, Loanware). Year of default is defined as year in which the sovereign defaulted on foreign-currency bond or bank debt according to Standard \& Poor's (Source: Beers and Bhatia, 1999). Source for gross private capital flows: WDI. For default years 1981, the data shown are numbers for 1980 instead of two-year averages. Number of defaults in 1980's: 49. Number of defaults in 1990s: 13. *Continued to access in 1998 . **Data for 2000 only. 


\section{REFERENCES}

Beers, David, and Ashok Bhatia, 1999, "Sovereign Defaults: Hiatus in 2000?," S\&P Credit Week (December 22).

Berg, Andrew, and Jeffrey Sachs, 1988, “The Debt Crisis," Journal of Development Economics, Vol. 29, pp. 271-306.

Brewer, Thomas L., 1990, "Politics and Perceived Country Creditworthiness in International Banking," Journal of Money, Credit, and Banking, Vol. 22, No. 3 (August), pp. 357-69.

Bulow, J., and Kenneth Rogoff, 1989, “Sovereign Debt: Is to Forgive to Forget?,” American Economic Review, Vol. 79 (June), pp. 43-50.

Calvo, Guillermo, Leonardo Leiderman, and Carmen Reinhart, 1993, "Capital Flows and the Real Exchange Rate Appreciation in Latin America: The Role of External Factors," IMF Staff Papers, International Monetary Fund, Vol. 40, No. 1 (March), pp. 108-151.

Cantor, R., and F. Packer, 1996, "Determinants and Impact of Sovereign Credit Ratings," Policy Review, Vol. 2 (October), Federal Reserve Bank of New York, pp. 37-53.

Cashin, Paul, and Catherine Pattillo, 2000, "Terms of Trade Shocks in Africa: Are They ShortLived or Long-Lived?” IMF Working Paper 00/72 (Washington: International Monetary Fund).

Catão, Luis, and Bennett Sutton, 2002, "Sovereign Defaults: The Role of Volatility," IMF Working Paper 02/149 (Washington: International Monetary Fund).

Chamberlain, G. (1978), "On the Use of Panel Data," paper presented at the Social Science Research Council Conference on Life-Cycle Aspects of Employment and the Labor Market, (Mount Kisco, N.Y).

Cohen, Daniel, 1991, Private Lending to Sovereign States: A Theoretical Autopsy (Cambridge, Massachusetts: MIT Press).

_ Repudiation," European Economic Review, Vol. 30, pp. 529-60.

Cole, H., J. Dow, and W. English, 1994, "Default, Settlement, and Signaling: Lending Resumption in a Reputational Model of Sovereign Debt, " Federal Reserve Bank of Minneapolis, Research Department Staff Report No. 180 (September).

and P. Kehoe, 1997, "Reviving Reputation Models of International debt," Federal Reserve Bank of Minneapolis Quarterly Review. Vol. 21 (Winter), pp. 21-30. 
Dell'Ariccia, Giovanni, Isabel Schnabel, and Jeromin Zettelmeyer, 2002, "Moral Hazard and International Crisis Lending: A Test," IMF Working Paper 02/181 (Washington: International Monetary Fund).

Detragiache, Enrica, and Antonio Spilimbergo, 2001, "Crises and Liquidity_Evidence and Interpretation, IMF Working Paper 01/2 (Washington: International Monetary Fund).

Dooley, Michael, 1994, "A Retrospective on the Debt Crisis.” NBER Working Paper No. 4963 (Cambridge, Massachusetts: National Bureau of Economic Research).

— Eduardo Fernández-Arias, and Kenneth Kletzer, 1996, "Is the Debt Crisis History? Recent Private Capital Inflows to Developing Countries," World Bank Economic Review, Vol. 10 (January), pp. 27-50.

Eaton, Jonathan, and Raquel Fernández, 1995, "Sovereign Debt," in Handbook of International Economics, ed. by Gene M. Grossman and Kenneth Rogoff, Vol. 3 (Amsterdam: North Holland).

_, and Mark Gersowitz, 1981, "Debt with Potential Repudiation: Theoretical and Empirical Analysis,” Review of Economic Studies, Vol. 48, pp. 289-309.

Edwards, Sebastian, 1986, "The Pricing of Bonds and Bank Loans in International Markets," European Economic Review, Vol. 30, pp. 565-89.

Eichengreen, Barry, 1989, “The U.S. Capital Market and Foreign Lending, 1920-1955," in Developing Country Debt and Economic Performance, ed. by Jeffrey D. Sachs; Vol. 1 (Chicago; London: University of Chicago Press), pp. 211-40.

, and Ashoka Mody, 1998, "What Explains Changing Spreads on Emerging Market Debt: Fundamentals or Market Sentiment?” NBER Working Paper No. 6408 (Cambridge, Massachusetts: National Bureau of Economic Research).

— 2000, "Lending Booms, Reserves and the Sustainability of Short-Term Debt: Inferences from the Pricing of Syndicated Bank Loans," Journal of Development Economics, Vol. 63, pp. 5-44.

and Richard Portes, 1989, "After the Deluge: Default, Negotiation and Readjustment During the Interwar Years," in The International Debt Crisis in Historical Perspective ed. by Barry Eichengreen and Peter Lindert (Cambridge, Massachusetts: MIT Press), pp. 12-47.

Fernandez-Arias, Eduardo, 1996, "The New Wave of Private Capital Inflows: Push or Pull?” Journal of Development Economics, Vol. 48, pp. 389-418.

Garibaldi, Pietro, Nada Mora, Ratna Sahay, and Jeromin Zettelmeyer, 2001, "What Moves Capital to Transition Economies?," IMF Staff Papers, Vol. 48, pp. 109-45. 
Gelos, R. Gaston, and Alejandro Werner, 2002, "Financial Liberalization, Credit Constraints and Collateral: Investment in the Mexican Manufacturing Sector," Journal of Development Economics Vol. 67, No.1, pp. 1-27.

Gibson, R., and S. Sundaresan, 2001, “A Model of Sovereign Borrowing and Sovereign Yield Spreads" (unpublished; New York: Graduate School of Business, Columbia University).

Grigorian, David, 2003, “On the First-Time Sovereign Bond Issues,” IMF Working Paper 03/184 (Washington: International Monetary Fund).

Hajvassiliou, Vassilis, 1987, “The External Debt Problems of LDC's: An Econometric Model Based on Panel Data," Journal of Econometrics, Vol. 36, pp. 205-30.

Hale, Galina, 2002,'Bonds or Loans? On the Choice of International Debt Instrument by Emerging Market Borrowers" (unpublished; University of California at Berkeley).

Hall, Robert, and Charles Jones , 1997, "Fundamental Determinants of Output per Worker Across Countries" (unpublished; Palo Alto, California: Stanford University).

Haque, Nadeem U1, Nelson Mark, and Donald Mathieson, 2000, "Rating Africa: The Economic and Political Content of Risk Indicators," in Investment and Risk in Africa, ed. by Paul Collier and Catherine Pattillo (New York: MacMillan).

Hsiao, Cheng, 1986, Analysis of Panel Data, (Cambridge: Cambridge University Press).

International Monetary Fund (IMF), 2001, Assessing the Determinants and Prospects for the Pace of Market Access by Countries Emerging from Crises. Prepared by the Policy Development and Review Department in consultation with other departments, September, available at $\mathrm{http}: / / \mathrm{www}$.imf.org/external/np/pdr/ma/2001/eng/ma.htm (Washington: International Monetary Fund).

Jorgensen, Erika, and Jeffrey Sachs, 1989, "Default and Renegotiation of Latin American Foreign Bonds in the Interwar Period," in Barry Eichengreen and Peter Lindert, eds., The International Debt Crisis in Historical Perspective (Cambridge, Massachusetts: MIT Press), pp. 48-85.

Kharas, Homi J., and Hisanobu Shishido, 1991, "The Transition from Aid to Private Capital Flows," in Uma Lele and Ijaz Nabi, eds., Transitions in Development: The Role of Aid and Commercial Flows (San Francisco: ICS Press).

Kletzer, Kenneth , 1994, "Sovereign Immunity and International Lending," in F. van der Ploeg, ed., The Handbook of International Macroeconomics (Oxford: Basil, Blackwell).

Lane, Phillip, 1999, "North-South Lending with Moral Hazard and Repudiation Risk," Review of International Economics, Vol. 7(1), pp. 50-58. 
— 2004, "Empirical Perspectives on Long-Term External Debt," Topics in Macroeconomics, Vol. 4, No.1, pp. 1-23.

Lensink, Robert, and P. A. G van Bergeijk, 1991, "The Determinants of Developing Countries' Access to the International Capital Market," Journal of Development Economics, Vol. 28, pp. 86-93.

— Capital Flows Mean the End of Aid? An Analysis of Developing Countries' Access to Private Capital," World Development, Vol. 26, No.7, 1221-1234.

Lindert, Peter H. and Peter J. Morton, 1989, "How Sovereign Debt Has Worked," in Jeffrey D Sachs, ed., Developing Country Debt and Economic Performance," Vol. 1 (Chicago and London; University of Chicago Press), pp. 39-106.

Lucas, Robert, 1990, “Why Doesn't Capital Flow from Rich to Poor Countries?” American Economic Review, Papers and Proceedings, Vol. 80 (May), pp. 92-96.

Manzano, Osmel, and Roberto Rigobon, 2002, "Resource Curse or Debt Overhang?," NBER Working Paper No. 8390 (Cambridge, Massachusetts: National Bureau of Economic Research).

McKenzie, David, 2002, "An Econometric Analysis of the Creditworthiness of IBRD Borrowers," World Bank Policy Research Working Paper No. 2822 (Washington).

Mody, Ashoka, and Antu Murshid, 2002, “Growing Up with Capital Flows,” IMF Working Paper 02/75 (Washington: International Monetary Fund).

— Commitment Devices?” IMF Working Paper 3/100 (Washington: International Monetary Fund).

— , and Mark Taylor, 2002, "International Capital Crunches: The Time-Varying Role of Informational Asymmetries,” IMF Working Paper 02/43 (Washington: International Monetary Fund).

Montiel, Peter, and Carmen Reinhart, 1999, "Do Capital Controls and Macroeconomic Policies Influence the Volume and Composition of Capital Flows? Evidence from the 1990s," Journal of International Money and Finance, Vol. 18 (4), pp. 619-35.

Obstfeld, Maurice, and Kenneth Rogoff, 1996, International Macroeconomics (Cambridge, Massachusetts: MIT Press).

Özler, Sule, 1992, "Evolution of Commercial Credit Terms: An Empirical Study of Commercial Bank lending to Developing Countries," Journal of Development Economics, Vol. 38, No. 1 (January), pp. 79-97. 
_ 1993, "Have Commercial Banks Ignored History?," American Economic Review, Vol. 83, No. 3, pp. 608-20.

— Working Paper No. 3772 (Cambridge, Massachusetts: National Bureau of Economic Research).

Pattillo, Catherine, Hélène Poirson, and Luca Ricci, 2002, "External Debt and Growth," IMF Working Paper 02/69 (Washington: International Monetary Fund).

Reinhart, Carmen M., Kenneth S. Rogoff, and Miguel A. Savastano, 2003, "Debt Intolerance," NBER Working Paper No. 9908 (Cambridge, Massachusetts: National Bureau of Economic Research).

Rogoff, Kenneth, and Carmen M. Reinhart, 2003, "FDI to Africa: The Role of Price Stability and Currency Instability,” IMF Working Paper 03/10 (Washington: International Monetary Fund).

Rose, Andrew, 2002, “One Reason Countries Pay their Debts: Renegotiation and International Trade" (unpublished: Haas School of Business, University of California at Berkeley).

Sachs, Jeffrey, 1984, “Theoretical Issues in International Borrowing,” Princeton Essays in International Finance No. 54 (Princeton, New Jersey: International Finance Section, Department of Economics, Princeton University).

— 1989, "The Debt Overhang of Developing Countries," in Debt, Stabilization, and Development, ed. by Guillermo Calvo, Ronald Findlay, Pentti Kouri, and Jorge Braga de Macedo (Oxford: Basil Blackwell).

Stiglitz, Joseph, and Andrew Weiss, 1981, "Credit Rationing in Markets with Imperfect Information," American Economic Review, Vol. 71, pp. 393-410.

Taylor, Mark, and Lucio Sarno, 1997, "Capital Flows to Developing Countries: Long- and Short-Term Determinants," World Bank Economic Review, Vol. 11, No. 3, pp. 451-70. 